\title{
COMMERCIAL LAW'S COMPLEXITY
}

\author{
David Frisch*
}

\section{INTRODUCTION}

We suffer today from a massive increase in the number and complexity of rules that govern social relations. ${ }^{1}$ Consider, for example, the many statutory sources of law that now regulate the various aspects of modern commercial practice. ${ }^{2}$ The center of this universe of codification is, of course, the Uniform Commercial Code ("UCC" or "Code"). ${ }^{3}$ Since first enacted by Pennsylvania in 1953, both the number of articles and the number of sections in the Code have multiplied dramatically.

The 1998 revision of UCC Article 9 is instructive. Although the statutory language of the pre-revision text was unquestionably simpler, the drafting committee had to weigh the implications of judicial decisions spanning more than four decades, as well as the societal changes they reflected. The

* Professor of Law, University of Richmond School of Law. B.S., University of Pennsylvania; J.D., University of Miami School of Law; LL.M., Yale Law School. I would like to thank participants at the University of Miami School of Law faculty colloquium who offered comments on an earlier draft of the Article. I also thank Blake Boyette, Humberto Portellez, and Jane Kendall for their research and editorial assistance.

1 This point is well made in RICHARD A. EPSTEIN, SIMPLE RULES FOR A COMPLEX WORLD 1-17 (1995). See also Charles S. PeirCE, Selected Writings (VAlues IN A Universe of Chance) 174 (Philip P. Wiener ed., Dover Publ'ns, Inc. 1966) (1958) ("Everywhere the main fact is growth and increasing complexity."); Peter H. Schuck, Legal Complexity: Some Causes, Consequences, and Cures, 42 DuKE L.J. 1, 6 (1992) (observing that the claims "that legal complexity is increasing, and that this is problematic for a system of justice-are not ... particularly controversial"). Various kinds of complexity sometimes result from the efforts of parties to contractually define their own legal relations. Thus, inter-firm contracts that contain a large number of interdependent provisions may be considered complex. See generally John Hagedoorn \& Geerte Hesen, Contractual Complexity of R\&D Alliances-A Two-Dimensional Analysis of the Determinants of Contractual Complexity (June 18, 2009) (unpublished manuscript), available at $\mathrm{http}: / / \mathrm{ssm} . c 0 m / a b s t r a c t=1367530$ (using a sample of R\&D contracts to develop a conceptual model of contractual complexity). A relatively recent academic enterprise has been to apply what we have learned from studying complex adaptive systems generally to the legal system in particular. See, e.g., J.B. Ruhl, Law's Complexity: A Primer, 24 GA. ST. U. L. REv. 885, 897 (2008) (observing that "the legal system exhibits all of the agent properties of complex adaptive systems").

2 Although much of what is contained in this Article would be relevant regardless of legal subject matter, this Article focuses primarily on statutory commands regulating commercial practice.

3 The Code, in one form or another, is the law in all fifty states, the District of Columbia, Puerto Rico, and the U.S. Virgin Islands. Jennifer S. Martin, An Emerging Worldwide Standard for Protections of Consumers in the Sale of Goods: Did We Miss an Opportunity with Revised UCC Article 2?, 41 TEX. INT'L L.J. 223, 224 n.1 (2006). Unless otherwise indicated, all references to Article 2 (Sales) and its sections are to the pre-2003 Article 2. All other references are to the 2009 Official Text of the UCC. 
result was not only more complex statutory language, but the addition of sixty-six new Code sections.

In addition to the normal periodic fine-tuning of existing UCC articles to reflect case law and significant societal change, ${ }^{4}$ several supplementary articles have been enacted as formal amendments to the Code in response to technological advances and modern business practices. ${ }^{5}$ For example, the development of computers, reader-sorter machines, image processors, and other electronic communication and processing equipment has given rise to new paperless systems for accomplishing high-value wire credit transfers. ${ }^{6}$ The task of "lawmaking" in response to this development could have been left to the marketplace by allowing the financial players who embraced the new payment system to drive a slowly developing common law. Instead, the Uniform Law Commission ("ULC"), which was until 2007 called the National Conference of Commissioners on Uniform State Laws, and the American Law Institute ("ALI") added a new Article $4 \mathrm{~A}$ to the Code in 1989 to avert uneven or unwelcome common law developments. ${ }^{7}$

Legislatures have also reacted to change by enacting auxiliary statutes covering subjects that are not consolidated into the Code. In 1996, for example, the ULC recognized both that electronic commerce could be improperly impeded by poorly conceived law and that the impact of new technologies extended beyond the existing scope of the Code to types of transactions not previously addressed. In response, the ULC established the Draft-

4 Within the past twenty years, the Uniform Law Commission ("ULC") and the American Law Institute ("ALI") have revised or amended U.C.C. Articles 1 (2001), 2 (2003), 2 A (2003), 3 (2002), 4 (2002), 5 (1995), 6 (1989), 7 (2003), 8 (1994), and 9 (1998). Although the particular impetus for each revision project has been somewhat different, the basic objective has always been to prevent the Code from becoming outdated. For example, since the promulgation of the 1957 Official Text of the Code, Article 2 has remained virtually unchanged. The same cannot be said, however, of commercial and consumer law generally and of the technological environments in which many transactions now take place. Some of the more obvious changes include the common law development of a theory of strict products liability that overlaps the Code, the enactment of a "hodgepodge of [federal and state] consumer protection legislation," and the growing use of electronic methods of contracting. Edith Resnick Warkentine, Article 2 Revisions: An Opportunity to Protect Consumers and "Merchant/Consumers" Through Default Provisions, 30 J. MARShall L. REv. 39, 78 (1996). One may wonder, therefore, why no state has so far enacted the 2001 version of either Article 2 or $2 \mathrm{~A}$. For one account of this fascinating story, see Jennifer S. Martin, supra note 3, at 224-38.

5 See, e.g., U.C.C. arts. 2A, 4A (2009).

6 See U.C.C. art. 4A prefatory note (2009).

7 For example, the Article $4 \mathrm{~A}$ drafting committee took issue with leading cases such as Evra Corp. v. Swiss Bank Corp., 673 F.2d 951 (7th Cir. 1982), which explained that consequential damages could be awarded if a bank, with notice of particular circumstances giving rise to damages, refuses to execute a payment order. $I d$. at $955-59$. The result is a statutory provision that bars consequential damages unless the bank expressly assumes such liability in writing. See U.C.C. $\$ 4$ A-305 cmt. 2 (2009). Article 4A does not apply to consumer funds transfers governed by the Electronic Fund Transfer Act, 15 U.S.C. $§ \$ 1693 \mathrm{a}-1693 \mathrm{r}$ (2006). Typical of these transfers are: point-of-sale transactions in which retail customers pay with a debit card, automated teller machine transactions, direct deposit of paychecks in consumer accounts, and preauthorized withdrawals from consumer accounts. 
ing Committee on Electronic Communications in Contractual Transactions, which was later renamed the Drafting Committee on the Uniform Electronic Transactions Act ("UETA"). Charged with drafting "such revisions to general contract law as are necessary or desirable to support transaction processes utilizing existing and future electronic or computerized technologies," the committee completed its work in 1999."

In recent years, commercial law reformers have taken particular aim at the law of software transactions. ${ }^{10}$ At the outset of the UCC Article 2 revision process, the ULC and ALI embarked on the path of incorporating software transactions into Article 2 by means of a so-called "hub and spoke" structure." The efficacy of this configuration was hotly contested, however, and in 1995, the leadership of both organizations abandoned the idea. Their next codification strategy was to address software transactions independently in the new Article $2 \mathrm{~B}$ of the Code. This article would have governed all contracts for the sale, licensing, development, distribution, maintenance, documentation, and support of computer software. However, after the drafting committee completed its work, the ALI withdrew its support for Article $2 \mathrm{~B}$, preventing it from becoming part of the UCC. The ULC then transformed the article into the free standing Uniform Computer Information Transactions Act ("UCITA"), ${ }^{12}$ a statute that, since its inception, has endured such heated criticism from consumer, business, and govern-

8 Memorandum from the Drafting Comm. on Elec. Commc'ns and Records to Scope and Program Comm. 2 (Jan. 3, 1997) (on file with the George Mason Law Review) (as approved by the Scope and Program Committee and the Executive Committee of the Conference).

9 Congress has also taken steps to provide for the legal effectiveness of electronic records and signatures. See Electronic Signatures in Global and National Commerce Act, 15 U.S.C. $\$ \S 7001-7031$ (2006). This statute is generally comparable, and defers, to state adoptions of the Uniform Electronic Transactions Act ("UET A"). Id. § 7002(a).

10 This Article does not attempt to address the fundamental question of whether we need a special set of rules to govern software contracts or whether traditional contract law principles are sufficientthat is, whether software transactions should be treated as a discrete contract class. It has been suggested, for example, that the commercial law should not recognize distinctions between tangible and intangible property. See Juliet M. Moringiello, False Categories in Commercial Law: The (Ir)relevance of (In)tangibility, 35 FLA. ST. U. L. REV. 119, 120 (2007) (arguing that "[c]lassifying property according to its tangibility or intangibility creates false categories unrelated to significant legal distinctions, and these false categories hinder the ability of commercial law to expand to adequately accommodate electronic assets").

11 Linda J. Rusch, A History and Perspective of Revised Article 2: The Never Ending Saga of a Search for Balance, 52 SMU L. REV. 1683, 1686 (1999) (internal quotation marks omitted). Professor Linda Rusch explains:

The discussions resulted in the eventual development of a "hub and spoke" concept whereby general contracting principles would be placed in a hub and provisions particular to each type of transaction would be placed in a separate spoke. The drafting committee contemplated a spoke for sales of goods, a spoke for leases, and a spoke for software licenses with the possibility of additional spokes being added later on.

Id.

12 For a brief summary of the reasons why the project was transformed into UCITA, see Nim Razook, The Politics and Promise of UCITA, 36 CREIGHTON L. REV. 643, 643-58 (2003). 
mental groups ${ }^{13}$ that it has been enacted in only two states. ${ }^{14}$ Elsewhere, two bodies of contract law-the common law ${ }^{15}$ and Article 2 of the Code ${ }^{16}$ compete to govern software contracts.

International developments in contemporary commercial law must be considered as well. Cooperative legislative measures in this arena are achieving international harmonization in several important areas. For example, the United Nations Convention on Contracts for the International Sale of Goods ("CISG" or "Convention") has significantly altered the landscape of the international law of sales. ${ }^{17}$ Since the CISG has the preemptive force of federal law, when applicable it supplants UCC Article 2, which in other circumstances continues to operate unfettered by the CSIG's principles and rules. Thus, buyers and sellers in the United States face two uniform legal texts, one for domestic and the other for international contracts for the sale of goods. ${ }^{18}$

13 See generally id.

14 I KATHERyn A. ANDRESEN, LAW AND BUSINESS OF COMPUTER SOFTWARE $\S$ 18:9(2009).

15 In a non-statutory effort to clarify and unify the law of software transactions, the ALI has recently produced what it calls the "Principles of the Law of Software Contracts." As explained in its introduction, "[c]ourts can apply the Principles as definitive rules, as a 'gloss' on the common law, U.C.C. Article 2, or other statutes, or not at all, as they see fit." AM. LAW INST,, PRINCIPLES OF THE LAW: SOFTWARE CONTRACTS 2 (2010).

16 Article 2 applies to "transactions in goods," U.C.C. $\S 2-102$ (2009), but "unless the context otherwise requires[,] 'contract' and 'agreement' are limited to those relating to the present or future sale of goods." Id. $\S 2-106(1)$. Indeed, the title of Article 2 is "Sales," and the definition of "goods" assumes a sale: "goods" is defined as "all things . . . which are movable at the time of identification to the contract for sale." $/$ d. § 2-105(1) (footnote omitted) (internal quotation marks omitted). So is the purchase of software a transaction in goods when most such transactions take the form of a license (i.e., there is no "passing of title from the seller to the buyer for a price")? Id. §2-106(1). Many courts have held that it is. See, e.g., Confer Plastics, Inc. v. Hunkar Labs. Inc., 964 F. Supp. 73, 77 (W.D.N.Y. 1997) (explaining that under New York and Ohio law, transactions involving sale of software constitute the sale of goods as defined in Article 2 of the UCC). Oklahoma has recently amended section 2-105 to specifically exclude information from the definition of goods and section 2-106 to add that "contract for sale" for purposes of Article 2 "does not include a license of information." See OKLA. STAT. ANN. tit. 12A, $\S \S 2-105(1), 2-106(1)$ (West 2008), amended by 2005 Okla. Sess. Laws 589.

17 For a good historical introduction to the CISG, see Franco Ferrari, Uniform Interpretation of the 1980 Uniform Sales Law, 24 GA. J. INT'L \& COMP. L. 183, 189-95 (1994).

18 Looking beyond interstate or international uniformity, there are also factors that undeniably promote the need for uniformity between domestic and international law. See, e.g., Richard E. Speidel, The Revision of UCC Article 2, Sales in Light of the United Nations Convention on Contracts for the International Sale of Goods, 16 Nw. J. INT'L L. \& BUS. 165, 170 (1995). Professor Speidel posits:

Although CISG and Article 2 operate in separate spheres, the transactions governed do not observe the sometimes arbitrary jurisdictional lines between domestic and international law. For example, uniformity would eliminate uncertainty and surprise over the scope of state (UCC) and federal (CISG) sales law and avoid disruptions in transactions that originate as domestic sales and conclude, through export, as international sales. This is particularly true where disputes over the quality of goods are directly involved. Since this import-export transaction pattern is a reality in international sales, a sharp line between domestic and international sales law seems contrived.

Id. (footnote omitted). 
As illustrated, numerous and varied sources of commercial law could be implicated in a given case, sometimes in an inconsistent or confusing fashion. An attorney practicing in the area of payments law, for example, faces competing sources of law and the difficult and immediate challenge of determining which legal regime governs the particular payment method at issue in each case. ${ }^{19}$ This feature of contemporary commercial law can be described as "external complexity."

Additionally, as the result of the law's "internal complexity," once the basic source of law is identified, legal uncertainty often arises as the attorney seeks to identify the applicable provisions within that source. Kipperman v. NetBank, FSB (In re Commercial Money Center, Inc. $)^{20}$ illustrates the barrier to efficient resolution of issues that can be created by internal complexity. In this case, Commercial Money Center, Inc. ("CMCI") was in the business of leasing equipment. It would package groups of leases together and assign only its right to receive future rentals to various entities, thus stripping the anticipated payment streams from the remainder of the leases. $^{21}$

In CMCI's bankruptcy, the trustee sought to avoid the transfer of the payment streams using the "strong arm" clause, codified in Bankruptcy Code $\S 544(\mathrm{a})(1)^{22}$, The assignee argued that, under the personal property categorization scheme of UCC Article 9, the underlying transactions involved the sale of payment intangibles. ${ }^{23}$ As such, the assignee's interest in the payment streams was automatically perfected upon attachment under Code section 9-309(3). The trustee, however, argued that the transaction was not a sale of payment intangibles, but was instead either a loan or a transfer of an interest in chattel paper. ${ }^{24}$ In that case, the assignee's interest in the payment streams could be perfected only by filing under section

19 William H. Henning \& Fred H. Miller, Status of the UCC: A Look Back at 2006, UCC BULL, July 2007 , at 2 . Some common illustrations follow:

Illustrations abound: there are error resolution procedures for debit and credit transfers but not for checks; there are liability limits for debit and credit transfers, but checks are still subject to negligence principles; and on and on. If a check, for example, starts out under the Code but ends up under the federal EFT Act due to conversion to an electronic communication, what rules apply and what sense is there in that approach?

Id. at $3 \mathrm{n.11}$; see also infra notes $162-74$ and accompanying text.

2056 U.C.C. Rep. Serv. (West) 54 (Bankr. S.D. Cal. 2005), aff'd in part, rev'd in part, and remanded, 350 B.R. 465 (B.A.P. 9 th Cir. 2006).

21 Id. at 56.

22 The strong-arm clause gives the bankruptcy trustee the rights and powers of a hypothetical judicial lien creditor. Since, under governing state law, an unperfected security interest would be subordinate to a judicial lien, U.C.C. $\$$ 9-317(a) (2009), Bankruptcy Code $\S 544$ (a)(1) empowers the trustee to avoid the unperfected security interest. 11 U.S.C. $\$ 544(a)(1)$ (2006).

23 U.C.C. § 9-102(61) (2009) ("Payment intangible' means a general intangible under which the account debtor's principal obligation is a monetary obligation.").

24 Chattel paper includes "a record or records that evidence both a monetary obligation and a ... lease of specific goods .... [Under this definition], 'monetary obligation' means a monetary obligation . . owed under a lease of the goods...." Id. § 9-102(11). 
9-310(a) or by taking possession of the lease agreements under section 9-313. Thus, a key issue in the case became the threshold matter of identifying the proper characterization of the transaction under the elaborate provisions of the UCC.

The bankruptcy court held for the trustee. ${ }^{25}$ However, as further evidence of the excessive internal complexity of the law, on appeal, the Bankruptcy Appellate Panel for the Ninth Circuit disagreed with the lower court as to the nature of the collateral. The Panel opined that the payment streams, having been stripped from the underlying chattel paper, reduced the transaction to the transfer of an interest in payment intangibles, for which automatic perfection was unavailable because the transaction was a loan. ${ }^{26}$

What are we to make of two courts reaching diametrically opposite results, each compelled by what it considers to be a clear, literal interpretation of identical statutory language? Even the two co-reporters for revised Article 9 took opposite sides as experts in the case. One concluded that the statutory language "does not state that a sale of any right evidenced by chattel paper carries with it the chattel paper itself," 27 while the other opined that "rights to payment evidenced by chattel paper . . . including the right to payment of some or all of the rent under a lease, continue to be classified as chattel paper." 28 In this instance, the only thing that can be said with confidence is that the choice of the governing Article 9 provision is a matter as to which reasonable judicial and commercial minds might differ. In any case, Commercial Money Center amply exemplifies the unacceptable costs of complexity and the need to find strategies or mechanisms for legal simplification.

A number of observers have argued that a movement toward brightline rules would make the law less complex, complexity being the direct result of the law's gradual evolution from precise rules to indeterminate standards. ${ }^{29}$ This view has been expressed with regard to a number of lawmaking activities, including administrative rulemaking, statutory drafting,

25 Commercial Money Ctr., 56 U.C.C. Rep. Serv. (West) at 60-61, 69-70. Alternatively, the bankruptcy court ruled that even if the payment streams were severable from the underlying leases, the automatic perfection rule of section 9-309(3) would nevertheless not apply because the true nature of the transactions were loans, not sales. $I d$. at 64-67.

26 NetBank, FSB v. Kipperman (In re Commercial Money Ctr., Inc.), 350 B.R. 465, 469 (B.A.P. 9th Cir. 2006).

27 Declaration of Charles W. Mooney, Jr. at 5, Kipperman v. NetBank, FSB (In re Commercial Money Ctr., Inc.), 56 U.C.C. Rep. Serv. (West) 54 (Bankr. S.D. Cal. 2005) (No. 02-09721-JH)

28 Declaration of Steven L. Harris at 10, Kipperman v. NetBank, FSB (In re Commercial Money Ctr., Inc.), 56 U.C.C. Rep. Serv. (West) 54 (Bankr. S.D. Cal. 2005) (No. 02-09721-H7). The bankruptcy court excluded the declarations of both Professor Mooney and Professor Harris. Commercial Money Ctr., 350 B.R. at 480 n. 12.

29 See Schuck, supra note I, at 10 ("A movement from rules to more complex standards has been evident for some time."). 
and case law development. Nor is it surprising that many commentators share this conception of the cause of, and cure for, legal complexity. On the face of things, it may seem evident that precise rules, by providing law administrators with less discretion, would serve the goal of reducing complexity. ${ }^{30}$ For example, who could reasonably claim to be in any way confused by the bright-line requirement that one must be at least thirty-five years old to be the President of the United States? ${ }^{31}$ Yet the plausibility and implications of alternative, if perhaps less intuitive, strategies for legal simplification deserve close examination and consideration. For example, one important goal of this Article is to advance a simplification strategy that rests on the counterintuitive idea that standards have the potential to reduce the law's complexity. An examination of the proposed strategies requires exploration of general questions about the relationship between commercial law and the expectations of the transactors who might be affected by that law.

This Article proceeds as follows. Part I briefly surveys prevailing ideas about the social costs of complexity and identifies additional costs that have escaped the attention of earlier commentators. The aim is to demonstrate why reducing the complexity of the commercial law system matters. Part II describes three legislative responses-two already enacted and one proposed-representing efforts to mediate the tension between the need for precise regulation and the generation of overly complex rules that often results. Part III provides a closer examination of these legislative responses and demonstrates that, taken together, they create an opportunity for the implementation of two strategies that may help to simplify the law by reconceptualizing its structure in a way that can be termed "minimalist." Part IV illustrates the application of these strategies by concrete examples demonstrating the benefits to be realized by their adoption.

\section{THE COSTS OF COMPLEXITY}

Internal and external complexity can negatively affect our commercial law system in at least three ways. The issues associated with these costs are both complex and important, meriting comprehensive development and exposition beyond the breadth of a single article. Nevertheless, even identification and a brief discussion of the costs will demonstrate that strategies are needed to blunt their impact.

30 See id. (noting that "the exercise of discretion in turn generates more legal complexity").

31 Professor Peter Schuck describes this particular rule as simple and contrasts it with the rule against perpetuities, which he describes as complex. Id. at 5 . 


\section{A. A Decline in Judicial Candor}

One consequence of allowing a commercial law system of competing rules (external and internal complexity) to exist is the opportunity it affords judges to engage in covert policymaking: a world with many rules provides judges with many choices. Critics have often asserted that judicial decision making suffers a loss of both predictability and transparency when judges are presented with multiple rules and no clear mandate to apply a particular one in a given situation. ${ }^{32}$

Concern for problems of judicial decision making has long attracted the attention of both judges and academics. Much of the literature they have produced has been devoted to a description of the factors that may determine how cases are decided ${ }^{33}$ including psychological factors that could play on the minds of judges..$^{34} \mathrm{~A}$ significant portion of the discussion is explicitly normative, focusing on the extent to which judges should candidly articulate the legal reasons for their opinions. ${ }^{35}$ Within this focus, two questions have been most prominent: first, are there instances when judges should be less than forthright when presenting the legal justifications for their opinions; and second, what are the costs associated with a lack of judicial candor?

In the theoretical debate over whether judicial candor should sometimes be sacrificed to achieve other worthwhile goals, ${ }^{36}$ Professor David Shapiro has surveyed and examined five possible justifications for judges to

32 Professor Karl Llewellyn used the fanciful term "[1] eeways of [p]recedent" to describe this problem of prediction and justification. See KARL N. LLEWELlyn, THE COMMON LAW TRADITION: DECIDING APPEALS 62 (1960).

33 See, e.g., Benjamin N. Cardozo, The Nature of the Judicial Process (1921); Frank M. Coffin, The Ways of a Judge: Reflections from the Federal appellate Bench (1980); LLEWELLYN, supra note 32.

34 See, e.g., Anthony Champagne \& Stuart Nagel, The Psychology of Judging, in THE PSYCHOLOGY OF THE COURTROOM 257, 262-64 (Norbert L. Kerr \& Robert M. Bray eds., 1982); Andrew S. Watson, Some Psychological Aspects of the Trial Judge's Decision-Making, 39 MERCER L. REV. 937, 938 (1988).

35 For present purposes, the term "candid" is being used to mean that the legal reasoning expressed in the opinion corresponds to what the judge believes to be the true justification for the holding. For a similar explanation of what constitutes judicial candor, see Scott Altman, Beyond Candor, 89 MiCH. L. REV. 296, 297 (1990) ("By candid, I mean never being consciously duplicitous. Candid opinions do not offer reasons judges know do not persuade them."). Interestingly, the definition of "candor" employed by Altman is similar to the definition Professor Micah Schwartzman uses to define the concept of "sincerity." See Micah Schwartzman, Judicial Sincerity, 94 VA. L. REV. 987, 992 (2008) ("If $A$ says that $p, A$ is sincere if and only if (i) $A$ intends to say that $p$ and (ii) $A$ believes that $p$."). On the other hand, Schwartzman defines "candor" more broadly to mean full disclosure. See id. at 996 ("Judge $J$ is candid if and only if $J$ discloses all information that $J$ believes is relevant to a legal decision.").

36 See David L. Shapiro, In Defense of Judicial Candor, 100 HARV. L. REv. 731, 739 (1987) (observing that "there are in the literature many eloquent statements of the need for some form of selective deception, or at least nondisclosure"). 
dissemble as identified by other commentators. ${ }^{37}$ The first such justification is described as "conscious dissembling ... [as a] way of maintaining a sense of our connection with the past"-for example, by distinguishing a controlling precedent rather than overruling it. ${ }^{38}$ Second, a lack of candor may be justified by the demands of collegiality-dissembling as a means of obtaining a majority opinion and desirable outcome. ${ }^{39} \mathrm{~A}$ third justification is fear of the effect of knowledge, as seen, for example, when judges opt to define "speech" rather than admit to less than absolute freedom of speech under the First Amendment. ${ }^{40}$ Fourth, judicial dissembling may be justified by situations involving "tragic choice," as when juries are permitted to acquit rather than convict defendants for murder in euthanasia cases to avoid unpalatable results. ${ }^{41}$ Finally, when judges must choose between legal and moral rights, some perceive an obligation for the judge to lie if necessary to preserve the moral right. ${ }^{42}$ Without entering into the debate over whether these justifications are valid, even if one accepts, arguendo, that honesty is not always the best policy, it is impossible to conclude that false judicial statements should be tolerated in the general run of cases. Certainly, no commentator has taken such a position. ${ }^{43}$ All agree that when the costs of dishonest judicial opinions are considered, a lack of candor should be tolerated (if at all) only in those infrequent cases in which there are extraordinary benefits to be gained. ${ }^{44}$ In the commercial law context, such cases would be rare indeed.

What, then, might be the costs of judicial opinions in which the underlying reasoning is inaccurately stated or obscured deliberately? At least five significant costs have been identified. First, opinions containing false representations as to their underpinnings fail to reinforce the crucial public belief that courts obey the law. ${ }^{45}$ This gives rise to a perception of illegitimacy by creating serious doubt that the ultimate outcome of litigation is based on

37 Id. at 739.

38 Id.

39 Id. at $742-43$.

40 Id. at $744-47$.

41 Id. at $747-49$.

42 Shapiro, supra note 36 , at $749-50$.

43 Id. at 738-39 (admitting that he "would . . . be hard-put to identify anyone who advocates deception across the board").

44 For example, Shapiro has no disagreement with Ronald Dworkin's thesis that a judge may lie when faced with a conflict between a legal and moral right. See id. at 749 (citing RONALD DwORKIN, TAKING RIGHTS SERIOUSLY 326-27 (1978)). To make his point, he posits the case of a state statute that is constitutional but nevertheless punishes individuals based on racial characteristics. Id.; see also Paul Butler, When Judges Lie (and When They Should), 91 MINN. L. REV. 1785, 1820 (2007) (stating that a moral theory of judicial subversion would "be limited to laws that violate bedrock principles of international law").

45 Butler, supra note 44 , at 1823. 
impersonal and reasoned judgments. ${ }^{46}$ Second, meaningful and productive dialogue among all participants in the legal system becomes impossible in the absence of judicial candor. Professors Martha Minow and Elizabeth Spelman and others have examined this cost, noting the resulting breakdown in real and mutually beneficial communication between lawyers and judges. ${ }^{47}$ Third, an important constraint on the exercise of judicial power is eroded when judges are less than honest. As David Shapiro has commented, "the limitations imposed by constitutions, statutes, and precedents count for little if judges feel free to believe one thing about them and to say another." ${ }^{248}$ Fourth, as will be more fully explored below in the discussion of unconscionability, legal doctrine is distorted when judges engage in covert methods of accomplishing public policy goals. ${ }^{49}$ Finally, there is the fact that being less than truthful is fundamentally immoral. Altman observes that "manipulation should be considered immoral on the ground that it is a form of insincere argument that in context makes the practice of legal justification less effective." $\$ 0$

The logic that suggests adherence to judicial openness applies equally at all levels of decision making. Whether trial or appellate, all courts need to take into account the costs associated with a lack of candor. If the past is any indication of what the future holds, though, there is little reason to believe that judges who are inclined to dissemble will cease to do so merely because of academic articles advocating an end to this form of judicial misbehavior. ${ }^{51}$ Thus, there is a need for a legislative strategy that will assert

46 See, e.g., id. ("The specter of widespread lying by judges could erode the legitimacy of the courts and ultimately threaten the rule of law.").

47 See, e.g., Altman, supra note 35, at 328 (suggesting that "if judges more accurately revealed the forces that move them to decide, lawyers and commentators would be able more directly to address judges' real concerns"); see also Martha L. Minow \& Elizabeth V. Spelman, Passion for Justice, 10 CARDOzo L. REV. 37, 55 (1988) ("Noble lies deceive the public, but over time, they can also deceive, and disservice, the liar. More explicit discussion of the bases for decisions promotes discussions that could meet the judge on his or her own turf-where he or she is actually confused or still wrestling.").

48 Shapiro, supra note 36, at 737 (arguing that "candor is the sine qua non of all other restraints on abuse of judicial power").

49 See infra notes $116-49$ and accompanying text.

50 Altman, supra note 35, at 331; see also Schwartzman, supra note 35, at 1027 (concluding that the "argument for the principle of judicial sincerity is based on the moral value of giving people reasons for the way in which the state treats them").

51 In an essay in which he discusses a lack of judicial candor regarding determinations of fact, Professor Anthony D'Amato reaches the pessimistic conclusion that judicial self-regulation is unlikely to remedy the problem because of an unwillingness on the part of judges to even discuss it. See Anthony D'Amato, Self-Regulation of Judicial Misconduct Could Be Mis-Regulation, 89 MICH. L. REV. 609, 623 (1990) (stating "that the judicial culture itself apparently has little room for countenancing disclosure of misbehavior that could undermine public confidence in the judiciary"). 
pressure toward candor while providing adequate flexibility for innovation. $^{52}$

\section{B. The Social Cost of Complexity: Higher-Priced, Lower-Quality Legal Services}

Given the literature on the subject, it is perhaps needless to note the direct correlation between the law's complexity and the demand for the services of expert lawyers. The economic effect of this increased demand is an increase in the cost of legal services. ${ }^{53}$ This phenomenon generates an interesting and previously unexplored question: does legal complexity artificially inflate the income of those in the legal profession while lowering the actual value of the advice they provide? There are indications that it does.

Strong empirical evidence exists for the predicted disparity between cost and value in legal services in recent works examining an analogous disparity evident in geographic variations in the delivery of health care services. Why, for example, are patients in Fort Myers, Florida, twice as likely to have back surgery as those in Miami? ${ }^{54}$ One of the most important findings in this literature is that communities can be identified by a "surgical signature" representing a locally preferred method of treatment for various diseases and injuries. ${ }^{55}$ In other words, in the medical world of multiple complex surgical alternatives, it is clear that where one lives will often determine how one is treated. A related finding that further provides inferential support for the claim about attorney's fees is that the variations result from a prevailing physician culture. For that reason, choices as to which health care services to deliver are not necessarily consistent with guidelines for optimally effective medical treatment. ${ }^{56}$ Rather, they are sometimes based on treatment trends within a community of health care providers-

52 Candor, to the extent it constrains judges, has the potential to impede the law's development. This Article offers a legislative strategy that accommodates both candor and development. See infra notes 175-214 and accompanying text.

53 See generally Michelle J. White, Legal Complexity and Lawyers' Benefit from Litigation, 12 INT'L REV. L. \& ECON. 381, 393 (1992) (noting that the more complex the law becomes the higher attorneys' legal fees become).

54 See Gilbert M. Gaul, When Geography Influences Treatment Options, WASH. PoST, July 24, 2005 , at $\mathrm{A} 12$.

55 See, e.g., James Staples King \& Benjamin W. Moulton, Rethinking Informed Consent: The Case for Shared Medical Decision-Making, 32 AM. J.L. \& MED. 429, $446-47$ (2006); Sharon Begley, Why Doctors Hate Science, NEWSWEEK, Mar. 9, 2009, at 49, 49 (stating that regional differences in prevalence of certain treatments result from "medical culture, not medical science" and that doctors "influence each other.").

56 King \& Moulton, supra note 55, at 447 (concluding that "the differences in patient treatment persist over time as a result of physician culture within hospitals and cities, rather than because of variances in patient preference or effective medical care"). 
and when that is the case, patients are being charged for a personalized medical decision that simply is not being made.

Conceptually related research has examined the choices made by lawyers and has uncovered a similar cultural influence. Professor Jean Braucher's detailed account of consumer bankruptcy practice exemplifies this research that suggests the significance of legal culture on legal choice. ${ }^{57}$ Braucher studied the filing practices of attorneys in Austin and San Antonio, Texas, and in Cincinnati and Dayton, Ohio, to identify the factors affecting the choice between Chapter 7 and Chapter 13 filings in consumer bankruptcy cases ${ }^{58}$ Especially close attention was paid to local administrative practices and legal culture. Braucher found that lawyers have a strong desire to conform to the local legal culture; hence, "there is a consumer bankruptcy law of each city, even of each law office." 59 One interviewee expressed his belief that "the biggest factor in chapter choice is who your lawyer is." ${ }^{60}$ Perhaps the strongest comments, though, came from an Austin lawyer who objected to the cultural pressure to file under Chapter 13. While advising clients to file under Chapter 13 is often "almost malpractice" in his view, this is done because of the prevailing culture. ${ }^{61}$ "The judges like them, the chapter 13 trustee likes them, creditors like them, the client likes them. I don't."'62

Moreover, in addition to the prevailing culture, financial factors may also prevent considerations of the client's circumstances from guiding the choice of chapter. ${ }^{63}$ Income cannot be optimized in a high-volume bankruptcy practice without standardizing legal services. Thus, lawyers tend to specialize in one chapter or the other, and each generally recommends that clients file under the chapter with which the attorney is most familiar. ${ }^{64}$ Since the complexity of the two bankruptcy options makes it difficult, if not impossible, for consumers to have informed input in the matter, dependence on attorneys for advice as to this important choice is perpetuated. In this

57 Jean Braucher, Lawyers and Consumer Bankruptcy: One Code, Many Cultures, 67 AM. BANKR. L.J. 501, 502-03 (1993).

58 Id. at 502 . Chapter 7 bankruptcy is a liquidation proceeding. The debtor turns over all nonexempt assets to the bankruptcy trustee, who then converts it to cash for distribution to unsecured creditors. 11 U.S.C. $\S \S 701-727$ (2006). Chapter 13 is also known as the "adjustment of debts" chapter. The debtor will pay off all or a portion of her debts over a five-year period. $I d$. $\S \S 1301-1330$.

59 Braucher, supra note 57 , at 502.

$60 I d$. at 504 (internal quotation marks omitted).

61 Id. at 508 (internal quotation marks omitted).

62 Id. (internal quotation marks omitted).

63 See Lars Lefgren \& Frank McIntyre, Explaining the Puzzle of Cross-State Differences in Bankruptcy Rates, 52 J.L. \& ECON. 367, 379 (2009) ("In jurisdictions in which courts allow high attorney fees for Chapter 13 bankruptcy, attorneys often push clients into Chapter 13, even if this is at odds with their best financial interests.").

64 Braucher, supra note 57 , at 543. 
environment, it is hard to comfortably conclude that consumers are receiving the maximum bankruptcy bang for their all-too-few bucks.

Unfortunately, key aspects of Braucher's findings likely apply with equal force to other areas in which lawyers must choose between competing and complex legal options. ${ }^{65}$ Consider, for example, the plethora of business entity forms that currently exist. ${ }^{66}$ These include corporations, ${ }^{67}$ subchapter $\mathrm{S}$ corporations, ${ }^{68}$ subchapter $\mathrm{C}$ corporations, ${ }^{69}$ professional corporations, ${ }^{70}$ nonprofit corporations, ${ }^{71}$ professional limited liability companies,${ }^{72}$ limited liability companies, ${ }^{73}$ joint venture companies, ${ }^{74}$ general partnerships, ${ }^{75}$ limited partnerships,${ }^{76}$ limited liability partnerships, ${ }^{77}$ limited liability limited partnerships, ${ }^{78}$ family limited partnerships, ${ }^{79}$ business trusts, ${ }^{80}$ real estate investment trusts, ${ }^{81}$ cooperative associations, ${ }^{82}$ and professional associations. ${ }^{83}$

In this complex field, the implications of Braucher's study are obvious. Lawyers facing financial and cultural constraints may fail to base their legal advice solely on the particular circumstances of each individual client when recommending the selection of a particular entity form. Their desire to conform to the prevailing culture in both their firm and locale may constrain them, as may the need to practice law efficiently by limiting the time spent on recurring activities rather than familiarizing themselves with the many tax and non-tax consequences of each option. ${ }^{84}$ The effect of all

65 Complexity, for example, has been identified as the cause of the so-called "legislative signature." See Vincent Di Lorenzo, Complexity and Legislative Signatures: Lending Discrimination Laws as a Test Case, 12 J.L. \& POL. 637, 639-41 (1996) (evaluating the relationship between complexity and legislative signatures in terms of the "chaos theory").

66 Because what really concerns us is that lawyers with business clients face difficult formation choices, it does not matter that all of the existing forms will not necessarily be available in any particular state.

67 See, e.g., DEL. CODE ANN. tit. 29, \$ 8224(a)(5) (2003).

68 See 26 U.S.C. $\$ 1361$ (a)(1) (2006).

69 See id. $\$ 1361(\mathrm{a})(2)$.

70 See, e.g., TEX. Bus. \& COM. CODE ANN. $\$ 71.002(5)$ (West 2007).

71 See, e.g., TEX. Bus. ORGS. CODE ANN. $\S 22.001$ (5) (West 2006).

72 See, e.g., ALA. CODE $\S 10-8$ A-1010 (LexisNexis 1999).

73 See, e.g., BUS. ORGS. $\$ 101.001(3)$.

74 See, e.g., DEL. CODE ANN. tit. 29, § 8224(a)(5) (2003).

75 See, e.g., Bus. ORGS. $\$ 152.001$.

76 See, e.g., ALA. CODE $§ 8-8-5$ (a).

77 See, e.g., BUS. ORGS. $\$ 153.351$.

78 See, e.g., ALA. CODE $\S 40-18-1(17)$.

79 See, e.g., GA. CODE ANN. § 48-5-7.4(A)(1)(C)(Iv) (2010).

80 See, e.g., ALA. CODE $\$ 7-1-201$ (b)(27).

81 See, e.g., id. § 40-14A-1(d).

82 See, e.g., id. § 2-13-112(5).

83 See, e.g., Colo. REV. STAT. ANN. § 12-25-105(2) (West Supp. 2006).

84 One scholar who is skeptical of the advantages of having an abundance of business forms is Professor Walter Schwidetzsky. See Larry E. Ribstein \& Mark A. Sargent, Check-the-Box and Beyond: 
this complexity in the law may very well be that clients, after paying for customized legal assistance, are receiving nothing more than off-the-rack advice.

\section{Legal Uncertainty}

No metric exists that can reliably measure the degree of uncertainty in a legal system. Nevertheless, to prevent cynicism and the deterioration of faith in the system, it is crucial to identify and address systemic characteristics that create or contribute to uncertainty. Of special significance for present purposes is the relationship between increasing external and internal complexity (i.e., more law) and correspondingly increasing uncertainty. ${ }^{85}$ Commentators have long argued over the extent to which the former begets the latter.

Notably, Professor William Landes and Judge Richard Posner have posited that complexity in the law may actually result in less uncertainty. ${ }^{86}$ They describe the process by which this occurs using a capital investment metaphor. Under Landes and Posner's model of judicial and administrative interpretations of legislative enactments, precedent is viewed as analogous to capital stock, the value of which will depreciate over time. ${ }^{87}$ This depreciation occurs when people change their behavior either to avoid disadvantageous judicial or administrative decisions based on the precedent or to adapt to new social conditions. ${ }^{88}$ When this happens, issues of first impression begin to arise to which the precedent does not apply, causing litigation outcomes to become less certain. The parties (or, more precisely, their law-

The Future of Limited Liability Entities, 52 BUS. LAW. 605, 617 (1997) ("As we consider what forms of business organizations may evolve in the future, we need to consider the fact that lawyers and their clients are awash in law now. ... If we have too many different entity statutes, ... the primary result may be not choice but confusion. When it comes to law, variety may be too much spice." (quoting the comments of Walter Schwidetzsky)).

85 The discussion in the text is limited to complexity caused by an increasing growth in statutes, cases, regulations, and the like. But, of course, legal complexity may have other causes, such as the stylistic manner in which many statutes are drafted. It is interesting to note that steps were taken by the ULC and the ALI to reduce this form of complexity when UCC Article 9 was being revised. See Louis F. Del Duca et al., Revisiting the Application of Plain English in Revising the UCC-Current Practice Among the Fifty States on Use of Captions in Legislation, 30 UCC L.J. 167, 167-69, 173 (1997); Louis F. Del Duca et al., Applying Plain English Techniques in Revising the UCC, 29 UCC L.J. 428, 428-29, 439-40 (1997).

86 William M. Landes \& Richard A. Posner, Legal Precedent: A Theoretical and Empirical Analysis, 19 J.L. \& ECON. 249, 269-70 (1976). Also among the "more is less" scholars is Professor Ronald Dworkin. See Ronald Dworkin, TAKING RightS SERIOUSLY 286 (1977) (arguing that if the legal system "is thick with constitutional rules and practices, and dense with precedents and statutes," the outcome of cases would be more predictable).

87 Landes \& Posner, supra note 86, at 250-51.

$88 I d$ at 263. 
yers) are then less likely to share the same perception of the statistical likelihood of particular outcomes. There are two key, interrelated implications of this developing uncertainty. First, the number of disputes can be expected to increase; and second, there will likely be a corresponding increase in the willingness of parties to litigate rather than settle out of court. ${ }^{89}$ As with economic markets, a corrective increase (investment) in the capital stock of precedent then takes place, continuing until the desired level of certainty (equilibrium) is restored to the system. ${ }^{90}$ Thus, Landes and Posner conjecture that more complexity in the law ultimately produces more certainty, just as fluctuations in the economy ultimately lead to stability through the self-correcting mechanisms of the market.

Other commentators paint a considerably less benign and more unsettling picture of the implications of complexity, correlatively questioning the theoretical model that underlies Landes and Posner's conclusion. ${ }^{91}$ The premise underlying this school of thought, in sharp contradistinction to that of Landes and Posner, is that the established trend toward uncertainty is likely to continue and that the growing body of both statutory and case law will only exacerbate the level of legal uncertainty. Professor Anthony D'Amato, for example, not only debunks the notion that the depreciation of precedent will lead to more litigation, but, more importantly, convincingly argues that reducing the volume of litigation and the number of statutes would increase legal certainty. ${ }^{92}$ As D'Amato explains:

\footnotetext{
The existence of a legal rule . . . invites persons disadvantaged by the rule to attack its content, and further encourages disadvantaged persons to modify their conduct so that the rule less certainly applies to them. One obvious way to reduce uncertainty in the law, therefore, is to repeal as many of the rules as possible. ${ }^{93}$
}

The simplest explanation for the causal relationship between complexity and uncertainty is that having more law on the books makes it more costly for those who might be affected by the law to familiarize themselves

89 Id. at $271-72$.

90 Id. at 272.

91 See, e.g., Anthony D'Amato, Legal Uncertainty, 71 CALIF. L. REV. 1, 8 (1983) (noting "that the increasing volume of litigation and rulemaking results in internal contradictions, a multiplication of ambiguities, and normative specifications that invite persons to avoid rules of law by planning their activities around them," thereby increasing uncertainty); Schuck, supra note 1, at 18 n.69 (observing that "[1] egal complexity and legal uncertainty are cognate concepts, but uncertainty is actually contingent on complexity").

92 D'Amato, supra note 91, at 15-18 (arguing that the unpredictability of outcomes makes settlement more likely because it accentuates the parties' aversion to risk and makes the costs of litigation greater).

93 Id. at $45-46$. The fact that people will adjust their behavior to avoid disadvantageous law is also employed by D'Amato to rebut Dworkin's thesis that more law makes outcomes more certain. See id. at 10. Another of D'Amato's rebuttal points is that "[s]uch increasingly dense 'legal information' can as easily confuse an issue as clarify it, and may also support conflicting resolutions." $I d$. at 9. 
with its content. ${ }^{94}$ Since individuals will not always be willing or able to pay the price necessary to inform themselves of the legal consequences of their behavior ${ }^{95}$ in explaining why some parties are ignorant of the law, it does not suffice to aver to a general lack of sophistication. The overabundance of law is not so much a trap for the unsophisticated-those who might be indifferent to legal requirements under any circumstances-as it is a disincentive for relatively sophisticated parties to plan their conduct with full understanding of the content of the law. A decrease in legal understanding can be expected to occur when the costs of gaining that understanding are perceived to be less than its benefits. Such might be the case when the parties have a low ex ante expectation that disputes are likely to arise or when the particular transaction is not thought to be of great value.

Moreover, common sense suggests that those who are called upon to interpret and apply the law (e.g., judges) are less likely to reach predictable results when confronted by internally or externally complex legal sources. For example, consider again the confusion that surrounds the source of law for software contracts, particularly identification of the law governing those transactions in "smart goods" (i.e, goods that contain computer information). The official comment that follows amended UCC section 2-103 states that "the sale of 'smart goods' such as an automobile is a transaction in goods fully within this article even though the automobile contains many computer programs. ${ }^{.96}$ Yet the same comment states that:

\footnotetext{
When a transaction includes both the sale of goods and the transfer of rights in information, it is up to the courts to determine whether the transaction is entirely within or outside of this article, or whether or to what extent this article should be applied to a portion of the transaction. $^{97}$
}

Since there is no further explanation, one is left to wonder just what it is that makes an automobile subject to Article 2. Is it that the goods portion of the transaction predominates? What if the jurisdiction uses the "gravamen test" for determining the applicability of Article 2 and the gravamen of the

94 Schuck, supra note 1, at 18 (suggesting that more law means that "[a]dministrators and subjects of such law must invest more in order to learn what it means, [and] when and how it applies").

95 Potentially, there are income distribution consequences that flow from this informational cost. Simply put, wealthy individuals are more likely than poor individuals to invest in procuring information about the law and are, therefore, better able to maximize the economic benefits of their transactions. See Werner Z. Hirsch, Reducing Law's Uncertainty and Complexity, 21 UCLA L. REv. 1233, 1246 (1974) ("In order to cope with the legal system resources are required that are less available to the poor than the rich; this is especially true where laws are precise or not well known. If laws are imprecise, then those who can afford the best legal advice tend to benefit more often than those who cannot.").

96 U.C.C. \$ $2-103 \mathrm{cmt} .7$ (2009).

97 Id. 
action involves the software? ${ }^{98}$ Further, if an automobile is the "easy" case, what about VCRs, DVDs, television sets, Palm Pilots, digital cameras, video game consoles, and a host of kitchen appliances that rely on software? And does the method of delivering software matter? For example, would software in an automobile be covered if it were purchased separately and then loaded into or electronically transmitted to the automobile? These are just some of the many questions that courts will be called upon to answer in common law fashion. With the ever-expanding array of software-driven products, it would be foolish to expect much certainty in this area of the law in the near future. ${ }^{99}$

Legal uncertainty is especially pernicious in those areas of human activity, such as commercial transactions, in which the unpredictability of legal outcomes renders individuals unable to plan their affairs without taking an undue risk. ${ }^{100}$ At their core, commercial transactions involve "deals," the principle end of which is to secure a value-maximizing exchange of property. The practical task facing contracting parties is to shape their transaction so that the burdens and risks are allocated in a manner acceptable to each. In order to do so effectively, it is absolutely essential that the parties have a basic understanding of applicable law. ${ }^{101}$ If the parties cannot feel secure at the outset that a court will act in a specific and predictable fashion, a coherent contract will not be possible, and neither party will be able to price his or her performance accurately. ${ }^{102}$ Deals will be less efficient, and some that would have been mutually beneficial will likely not

98 See Eniola Akindemowo, Contract, Deposit or E-Value? Reconsidering Stored Value Products for a Modernized Payments Framework, 7 DEPAUL BUS. \& COM. L.J. 275, 303-04 (2009) (discussing how the "gravamen test" helps courts determine the applicability of Article 2 to software action).

99 In those jurisdictions that choose to take their source of law cue from the new Principles of the Law of Software Contracts, a predominant purpose test would be applied. Section 1.07(a) states: "[T]hese Principles apply to agreements for the transfer of software embedded in goods if a reasonable transferor would believe the transferee's predominant purpose for engaging in the transfer is to obtain

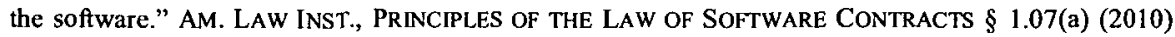
Even the Reporters admit that the application of this test "creates a line-drawing challenge." Id. $\S 1.07$ (a) cmt. d.

100 Predictability is the most common justification for precedent. See David Lyons, Formal Justice and Judicial Precedent, 38 VAND. L. REV. 495, 496 (1985) ("The reason most often given for the practice of precedent is that it increases the predictability of judicial decisions."); Earl Maltz, The Nature of Precedent, 66 N.C. L. REV. 367, 368 (1988) ("The most commonly heard justification for the doctrine of stare decisis rests on the need for certainty in the law.").

101 See, e.g., Lewis F. Powell, Jr., Stare Decisis and Judicial Restraint, 47 WASH. \& LEE L. REV. $281,286(1990)$ (noting that predictability of outcome "is especially important in cases involving property rights and commercial transactions").

102 Max Weber observed: "[T]he rationalization and systematization of the law in general and ... the increasing calculability of the functioning of the legal process in particular, constituted one of the most important conditions for the existence of . . capitalistic enterprise, which cannot do without legal security." 2 MAX WEBER, ECONOMY AND SOCIETY: AN OUTLINE OF INTERPRETIVE SOCIOLOGY 883 (Guenther Roth \& Claus Wittich eds., Univ. of Cal. Press 1978) (1968). 
take place at all; thus the law, due to legal uncertainty, will have hindered rather than facilitated commerce.$^{103}$ Legal certainty and predictability, on the other hand, serve the instrumentalist goal of promoting market transactions-in a capitalistic society, the primary means of allocating resources from less to more valuable uses.

Moving the law in the direction of increased certainty can be expected to produce a corresponding reduction in the inefficient costs associated with litigation. ${ }^{104}$ Most contemporary accounts of uncertainty posit that parties who can bargain and who are acting in an economically rational manner will not go to court to settle a dispute unless the two sides have dissimilar perceptions as to how the parties can be expected to fare in litigation. ${ }^{105}$ Consider first a dispute in which Party A and Party B share the same belief that litigation would yield a 75 percent probability of Party A winning and a 25 percent probability of Party B winning. ${ }^{106}$ If Party A's claim is for $\$ 1,000$ and each party would be required to spend $\$ 100$ to litigate, the parties would be foolish not to settle. ${ }^{107}$ If the case were to go to trial, the net expected benefit to Party A would be $\$ 650$ ( 75 percent of $\$ 1,000$ minus the litigation costs), and the net expected loss to Party B would be $\$ 850$ (75 percent of $\$ 1,000$ plus the litigation costs). Hence, both parties would benefit by settling for an amount between $\$ 650$ and $\$ 850$. On the other hand, if, because of the law's uncertainty, each party perceives the situation differently and believes that she has a 75 percent chance of winning, the outcome radically changes. Now, although Party A would settle for any amount greater than $\$ 650$, Party B would be unwilling to offer more than

103 Others have made similar observations. See, e.g., D'Amato, supra note 91, at 5 ("If rules relating to sales, commercial paper, negotiable instruments, deeds, wills, and the like approach . . . complete uncertainty, the underlying commercial activities will be deterred if not stifled."); Julian N. Eule, Temporal Limits on the Legislative Mandate: Entrenchment and Retroactivity, 1987 AM. B. FOUND. RES. J. 379, 440 ("Advance planning is necessary for economic development. Investments that will be legally as well as financially speculative are less likely to be undertaken. Those who rely on existing law are undoubtedly entitled to certain assurances that their interests will not be undervalued or ignored by future lawmakers."); Schuck, supra note 1, at 19 (suggesting that "[i]n fields as diverse as agency regulation, trusts and estates, and torts, complexity can inhibit beneficial transactions"). Consider also the ALl's command to its restatement reporters "to help make certain much that is now uncertain and to simplify unnecessary complexities." Report of the Committee on the Establishment of a Permanent Organization for the Improvement of the Law Proposing the Establishment of an American Law Institute, 1 A.L.I. PROC. 1, 14 (1923).

104 These would include both the private financial and "psychic costs" that must be paid by the parties who are unable to settle their disputes and the social costs of maintaining and running the legal system. Hirsch, supra note 95, at 1236-37.

105 See, e.g., Richard A. POSNER, ECONOMIC ANALYSIS of LAW 434-41 (2d ed. 1977); Hirsch, supra note 95, at 1236-37. But see D'Amato, supra note 91, at 15-18 (arguing that the parties' incentives to litigate are decreased if they have a negative or positive aversion to risk and when one factors in the added expense of researching and litigating an uncertain legal issue).

106 The essential features of this example are borrowed from Hirsch, supra note 95, at 1237 n. 10.

107 This conclusion assumes that the costs of settlement would be less than $\$ 100$. 
her expected loss of $\$ 350$ (25 percent of $\$ 1,000$ plus the litigation costs). By implication, if each side perceives itself as likely to be victorious in litigation, no settlement amount would be seen as having the potential to improve on that outcome.

Complexity admittedly does not account entirely for the law's uncertainty. Unexpected legal outcomes resulting from unanticipated contingencies cannot be altogether eliminated, even by the most careful statutory drafting. Nor would skillful drafters want to risk the perils widely associated with overly particular statutory terms. ${ }^{108}$ In addition, interpretation of a statute is sometimes complicated by new technologies and evolving business practices. ${ }^{109}$ Application must take into account considerations of both fact and policy, about which reasonable minds may differ. Moreover, statutory law has no monopoly on the adverse effect of unpredictability in interpretation and application; in fact, the "legal realists" pointed out the same phenomenon with regard to case law more than seventy-five years ago. ${ }^{110}$

108 Apart from the inevitable indeterminacy of statutory formulations, see Anthony D'Amato, Counterintuitive Consequences of "Plain Meaning", 33 ARIZ. L. REV. 529, 530-34 (1991), inherent in any piece of legislation is what Professor Hart called an "indeterminancy of aim." H. L. A. HART, THE CONCEPT OF LAW 128 ( $2 \mathrm{~d}$ ed. 1994). To make this point, Hart posits an ordinance barring vehicles from a public park. Id. at 128-29. If the purpose of the law is to maintain peace and quiet, then it is likely that the legislature intended to banish cars, buses, and motorcycles; it is unclear whether other "vehicles" were intended to be excluded.

We have initially settled the question that peace and quiet in the park is to be maintained at the cost, at any rate, of the exclusion of these things. On the other hand, until we have put the general aim of peace in the park into conjunction with those cases which we did not, or perhaps could not, initially envisage (perhaps a toy motor-car electrically propelled) our aim is, in this direction, indeterminate. We have not settled, because we have not anticipated, the question which will be raised by the unenvisaged case when it occurs: whether some degree of peace in the park is to be sacrificed to, or defended against, those children whose pleasure or interest it is to use these things.

Id. at 129

109 This has certainly been the case with the UCC. For example, in the course of assessing the ability of paper-based legal requirements to accommodate technological change, a number of difficult issues arise. One is whether the electronic message can be brought within the definitions of "written" or "writing," see U.C.C. § 1-201(b)(43) (2009), and "signed," see id. § 1-201(b)(37), in order to satisfy the section 2-201 statute of frauds requirements. There seems to be little consensus on the proper disposition. For a collection of views, see generally Sharon F. DiPaolo, Note, The Application of the Uniform Commercial Code Section 2-201 Statute of Frauds to Electronic Commerce, 13 J.L. \& COM. 143, 145 55 (1993). For a catalogue of commercial innovations that have arisen since the adoption of the Code, see generally John F. Dolan, Changing Commercial Practices and the Uniform Commercial Code, 26 LOY. L.A. L. REV. 579, 582-92 (1993).

110 The term "legal realism" has its genesis in an article by Karl Llewellyn. See Karl N. Llewellyn, A Realistic Jurisprudence - the Next Step, 30 CoLUM. L. REV. 431, 448-49 (1930). Professor Morton J. Horwitz explained that "[r]ealism was neither a coherent intellectual movement nor a consistent or systematic jurisprudence. It expressed more an intellectual mood than a clear body of tenets, more a set of sometimes contradictory tendencies than a rigorous set of methodologies or propositions about legal theory." MORTON J. HORWITZ, THE TRANSFORMATION OF AMERICAN LAW 1870-1960: THE CRISIS OF LEGAL ORTHODOXY 169 (1992). Horwitz went on to note that "above all, Realism is a continuation of the Progressive attack on the attempt of late-nineteenth-century Classical Legal Thought to create a 
The diverse theorists who founded the legal realism movement shared a common skepticism regarding the existence and structure of determinate and non-discretionary answers to legal questions. ${ }^{111}$ For them, law was not a structure of neutral and nonpolitical norms that could be disengaged from the realities of life. Rather, the inevitable connection between law and life was valued as the means by which the common law could evolve to reflect the needs of society. ${ }^{112}$

As Judge Jerome Frank has explained, to secure the benefits associated with legal change, some legal certainty must be sacrificed:

\begin{abstract}
Legal predictability is plainly impossible, if, at the time I do an act, I do so with reference to law which, should a lawsuit thereafter arise with reference to my act, may be changed by the judge who tries the case. For then the result is that my case is decided according to law which was not in existence when $I$ acted and which $I$, therefore, could not have known, predicted or relied on when I acted.

If, therefore, one has a powerful need to believe in the possibility of anything like exact legal predictability, he will find judicial lawmaking intolerable and seek to deny its existence.

Hence the myth that the judges have no power to change existing law or make new law: it is a direct outgrowth of a subjective need for believing in a stable, approximately unalterable legal world-in effect, a child's world. ${ }^{13}$
\end{abstract}

Nevertheless, recognizing that some degree of legal indeterminacy is an inevitable byproduct of the healthy evolution of common law, the costs associated with indeterminacy still dictate that steps should be taken to mi-

sharp distinction between law and politics and to portray law as neutral, natural, and apolitical." Id. at 170 .

111 See, e.g., AMERICAN LEGAL REALISM 164 (William W. Fisher III et. al. eds., 1993) (describing the Realist view that 'judges sometimes to some degree pay attention to the 'paper rules,' but . . they are also influenced powerfully by other considerations").

112 See, e.g., S. Pac. Co. v. Jensen, 244 U.S. 205, 221 (1921) (Holmes, J., dissenting) (observing that "judges do and must legislate"), superseded by statute, Longshoreman's and Harbor Workers" Compensation Act $\S 3(\mathrm{a}), 86$ Stat. 1251, 1265,33 U.S.C. $\S 903$ (a) (1972), as recognized in U.S. Dep't of Labor v. Perini N. River Assocs., 459 U.S. 297 (1983); Jabez Fox, Law and Fact, 12 HARV. L. REV. 545,548 (1899) (recognizing that "judicial legislation . . . is inherent in the strict performance of judicial duty"); Phillip B. Kurland, Jurisdiction of the United States Supreme Court: Time for a Change?, 59 CORNELL L. REV. 616, 618 (1974) (observing that the ability of courts to make law "is the genius of the common law system that we inherited from our English forebears"). Justice Cardozo's cognizance of the lawmaking role of courts is evident in the following excerpt from his essays on the craft of judging:

I was much troubled in spirit, in my first years upon the bench, to find how trackless was the ocean on which I had embarked. I sought for certainty. I was oppressed and disheartened when I found that the quest for it was futile. I was trying to reach land, the solid land of fixed and settled rules .... As the years have gone by ... I have become reconciled to the uncertainty, because I have grown to see it as inevitable. I have grown to see that the process in its highest reaches is not discovery, but creation....

Benjamin N. Cardozo, The Nature of the Judicial Process 166 (1921). Notwithstanding the foregoing, political events have taught us that, in at least one context, a change in law by a state court is prohibited by federal statutory and constitutional law. See Bush v. Gore, 531 U.S. 98, 104-10 (2000).

113 JEROME FRANK, LAW AND THE MODERN MIND 34-35 (1935). 
nimize the degree of uncertainty to the greatest extent possible. If complexity is a source of uncertainty that can be reduced without offsetting social costs, efforts should be made to do so.

\section{SOME SPECIFIC RESPONSES-UNDERTAKEN AND PROPOSED-TO LEGAL COMPLEXITY AND ITS CONSEQUENCES}

Against this background, we have predictably seen occasional efforts by legislatures to mediate the tension between the law's development and its complexity. Since a complex legal environment tends to increase transaction costs and create inefficiencies for society in the aggregate, ${ }^{114}$ there will always be those who propose simplification strategies, which are sometimes adopted. ${ }^{115}$ Several brief accounts of ways in which law and policy have responded to complexity and its consequences are examined in this section.

\section{A. The Doctrine of Unconscionability}

The case law and literature relating to the doctrine of unconscionability provide a rich resource for exploring ideas about candor in the judicial process. ${ }^{116}$ It has been noted by a number of commentators that the UCC section addressing unconscionability ${ }^{17}$ was an explicit policymaking effort

114 The earlier discussion of the costs of complexity is neatly summed up by the following conclusion reached by Henry Hart and Albert Sacks:

Two chief defects in American law are its uncertainty and its complexity. These defects cause useless litigation, prevent resort to the courts to enforce just rights, . . . and when litigation is begun, create delay and expense[,] ... which but for the law's uncertainty would be avoided.

Henry M. HaRT, JR. \& Albert M. SaCks, The Legal Process: Basic Problems in the Making AND APPLICATION OF LAW 750 (1958).

115 Sometimes - for very good reasons--there is a backlash against complexity and an attempt to move toward simplification. Schuck elaborates:

Complexity's costs . . . can be ignored, rationalized, and multiplied for a time, perhaps for a long time. Eventually, however, they become insupportable. The political momentum and behavioral incentives reach a critical juncture; countervailing pressures for simplification begin to affect both the law and how people respond to the law. . . Many producers and consumers of the law ... are devising strategies to contain, circumvent, and turn complexity to their own advantage.

Schuck, supra note 1, at $39-40$.

116 See supra notes 32-52 and accompanying text (discussing complexity and its impact on judicial candor).

117 UCC section 2-302 provides in pertinent part as follows:

If the court as a matter of law finds the contract or any clause of the contract to have been unconscionable at the time it was made the court may refuse to enforce the contract, or it may enforce the remainder of the contract without the unconscionable clause, or it may so limit the application of any unconscionable clause as to avoid any unconscionable result.

U.C.C. $\$ 2-302(1)(2009)$. 
by drafter Professor Karl Llewellyn that was designed to provide courts with a doctrine that would allow them to decide cases honestly and without the need to manipulate established but poorly-fitting legal concepts. ${ }^{118}$ This purpose is expressly revealed in Comment 1 to the section, which reads, in part, as follows:

This section is intended to make it possible for the courts to police explicitly against the contracts or clauses which they find to be unconscionable. In the past such policing has been accomplished by adverse construction of language, by manipulation of the rules of offer and acceptance or by determinations that the clause is contrary to public policy or to the dominant purpose of the contract. This section is intended to allow the court to pass directly on the unconscionability of the contract or particular clause therein and to make a conclusion of law as to its unconscionability. ${ }^{119}$

In addition to the four evasive techniques identified in the comment, the section also created a viable alternative to a host of other common law doctrines formerly employed by courts when confronted, for example, with the

118 See, e.g., M. P. Ellinghaus, In Defense of Unconscionability, 78 YALE L.J. 757, 764 (1969) ("Still, if the question is asked: What does Section 2-302 add to the techniques already available for dealing with deceptive bargaining practices, then it must be answered: nothing much except a greater possibility of overtness in place of covertness."); Arthur Allen Leff, Unconscionability and the Codethe Emperor's New Clause, 115 U. PA. L. REv. 485, 527 (1967) ("What [the cases in the Comment] do illustrate, however, and quite well, is the skewing of legal doctrine that may be caused by an emotional pressure to get a more heartwarming particular result." (footnote omitted)); John A. Spanogle, Jr., Analyzing Unconscionability Problems, 117 U. PA. L. REV. 931, 934 (1969) ("Courts used lack of mutuality, failure of consideration, and construction of contract terms to achieve desired results in situations where they would not traditionally have been used." (footnotes omitted)). Karl Llewellyn was the coordinator of the Code project and the individual primarily responsible for drafting original Articles 1 and 2. He was also one of the most influential figures in the realist assault on the conceptualism of the old order. See generally WILLIAM TWINING, KARL LLEWELLYN AND THE REALIST MOVEMENT 87-374 (1973) (providing an interpretation of Llewellyn's thought and its development). Llewellyn believed in finding the law in the commercial context that gave rise to the dispute. Accordingly, the judicial task was to discover this so-called "immanent law." That Llewellyn assigned for himself the responsibility of drafting Article 2 is not surprising. After all, the sales construct is a peculiarly appropriate model for the drafting style that Llewellyn had in mind. Unlike the other articles of the Code, Article 2 contemplates an essentially bipartite transaction between a seller and a buyer. See U.C.C. art. 2 (2009). Third parties may play a role, but their participation is essentially minor. In the sales context, the values of certainty and predictability are able to take a back seat to the need to divine and fulfill the parties' expectations created by their factual bargain. Seen in this light, Article 2 is a "jurisprudential statement." See Peter A. Alces, Roll Over, Llewellyn?, 26 LOY. L.A. L. REV. 543, 543 (1993).

119 U.C.C. $\$ 2-302$ cmt. 1 (2009); see also I STATE OF NEW YORK LAW REVISION COMMISSION REPORT: STUDY OF THE UNIFORM COMMERCIAL CODE 730 (William S. Hein \& Co. reprt. ed. 1980) (1955) [hereinafter NEW YORK UCC STUDY] ("The statement in the Comment concerning the purpose of Section 2-302 has been supplemented by Professor Llewellyn's remarks at the Commission's hearing on Article 2, and by the Editorial Board's Subcommittee on Article 2 at a meeting with a committee of the Commission held October 26, 1955. The purpose, as so indicated, is not to enlarge the area in which agreements of the parties will be defeated by judicial action on the ground of unfaimess or undue harshness, but to require that the question of unconscionability be dealt with directly . . ..). 
" "pore-ole-widder-lady' syndrome" 120 and motivated to do the "right" thing. These doctrines included, among others, fraud, duress, undue influence, and lack of capacity. ${ }^{121}$

Evidence suggests that section 2-302 emerged from Llewellyn's own calculus of the costs and benefits associated with what he perceived to be the less-than-forthright manner in which courts reacted against harsh contractual provisions. ${ }^{122}$ In Llewellyn's view, the willingness of courts to perceive the unfairness of a particular clause or contract and attempt to rectify it, even through misconstruction of contract language or misapplication of particular doctrines, still served to rein in opportunistic sellers and more fairly allocate risks. ${ }^{123}$ However, Llewellyn recognized that these indirect methods came with their own cost of "unnecessary confusion and unpredictability"124 and that, in his words, "[c]overt tools are never reliable tools." 125 His statutory doctrine of unconscionability was an attempt to minimize costs by providing courts with a less problematic alternative for remedying unfairness.

It should be observed that evaluation of the performance of section 2-302 has not always been positive. One criticism has been that decisions are made and conclusions reached without adequate explanations by courts of the factors they found necessary or sufficient to support their holdings. ${ }^{126}$ A case that has been used to illustrate this shortcoming of the unconscionability framework is Bank of Indiana $v$. Holyfield. ${ }^{127}$ In Holyfield, the defendants, Mr. and Mrs. Holyfield, were dairy farmers who leased several cows from a company that was subsequently merged into the plaintiff bank. ${ }^{128}$ The lease agreement between the parties provided that the Holyfields' obligations under the lease would continue even if the cows were destroyed through no fault of the Holyfields. ${ }^{129}$ When many of the leased cows died as the result of a storm and the Holyfields could no longer comply with the

120 Leff, supra note 118 , at 527.

121 See generally Robert A. Hillman, Debunking Some Myths About Unconscionability: A New Framework for U.C.C. Section 2-302, 67 CORNELL L. REV. 1, 6, 19 n.101 (1981).

122 See Leff, supra note 118, at 525-27.

123 See K. N. Llewellyn, 52 HARV. L. REV. 700, 702 (1939) (book review) ("[W]e have developed a whole series of semi-covert techniques for somewhat balancing these bargains.").

124 Id. at 703.

$125 \mathrm{Id}$.

126 Because the Code does not define the term "unconscionable" and leaves courts to their own devices to make sense of this limitation on freedom of contract, Professor Leff asks whether we are better off "when there is substituted for the court's obligation to give false reasons for its behavior, a specific power to give no reason at all." Leff, supra note 118, at 527. It is this Article's contention that we are.

127476 F. Supp. 104 (S.D. Miss. 1979). Robert Hillman provides a critical discussion of this case. See Hillman, supra note 121, at 19-20.

128 Holyfield, 476 F. Supp. at 105.

129 Id. at 107. 
terms of the lease, the lessor sought to recover the delinquent payments as damages. ${ }^{130}$

The district court found that the lease was "too one-sided" to be conscionable ${ }^{131}$ noting a number of factors: the Holyfields were not welleducated; ${ }^{132} \mathrm{Mr}$. Holyfield had not been given an opportunity to read the lease before signing it; ${ }^{133}$ the provisions in the lease had not been explained to Mr. Holyfield prior to signing: ${ }^{134}$ the lease was a contract of adhesion, having been presented to the Holyfields "on a 'take-it-or-leave-it' basis" by a party who was in a superior bargaining position; ${ }^{135}$ the Holyfields were victims of "the somewhat sub rosa manner in which the [lessor] operated through its broker and his employee;" 136 and the plaintiff had failed to procure adequate insurance for the cows. ${ }^{137}$

The court did not, however, indicate which of the foregoing factors were necessary or sufficient to support its finding of unconscionability. ${ }^{138}$ Critics have pointed out that, given the lack of express guidance in the court's opinion, Holyfield and other such cases offer little to those attempting to gauge their actions on the basis of judicial precedent. ${ }^{139}$ Nevertheless, support for an unconscionability provision solely on the basis of this flaw misses a more salient point. The emphasis should rest on the intrinsic benefits of section 2-302, which far outweigh its costs. Consider the notion that misconstruction of language or misuse of doctrine to achieve a desired outcome has a corrupting influence on the evolutionary process of the law's development and lessens the predictability of future cases. Because this doctrinal straining, once permitted, is not expressly reserved for unfair contracts, it is just as likely to be employed in cases involving fair ones. If it is, the subsequent course of development of the law could produce inappropriate results generally - and even if it does not, the predictive value of case law remains impaired and greatly diminished. ${ }^{140}$

138 See Hillman, supra note 121, at 20. Cases like Holyfield, therefore, have led to the suggestion that the application of common law assent doctrines would improve the clarity of opinions. See id. ("Had the court applied common law assent doctrines, it would have helped to direct the inquiry and pinpoint the crucial issues.").

139 See, e.g., id. at 20-21.

140 See, e.g., Spanogle, supra note 118, at 934 (noting that "indiscriminate application of the doctrines was extremely unsettling and caused great difficulty in predicting the courts' handling of normal, fairly drafted contracts").
} 
In drafting section 2-302, Llewellyn consciously created a statute that requires a court to familiarize itself with relevant commercial practices:

[It does this] by utilizing flexible standards, such as commercial reasonableness and good faith, rather than rules that purport to capture and solidify prevailing practices and norms. Each dispute between a seller and buyer is placed in its functional setting where the parties are expected to find and prove relevant "habits," i.e., trade usage or practices as part of the agreement. Under these standards, the court is given flexibility (at some cost to certainty and administrability) to resolve the new or unique dispute. Moreover, standards are thought to reduce the gap between law and practice and to insure that decisions are practical and responsive to the needs, proven in the particular case, of the parties and the relevant business community. ${ }^{141}$

This emphasis on real commercial life finds expression in the portion of section 2-302 that mandates a hearing prior to a finding of unconscionability. ${ }^{142}$ Deciding difficult cases involves identifying, examining, and understanding the commercial context in which the disputed clause or contract was drafted. The deliberate imprecision of section 2-302, together with ambiguity in the case law, in fact produces the power of the unconscionability doctrine. It enables courts to discern and reach a result consistent with the immanent justice of a situation. ${ }^{143}$

In sum, courts no longer need to strain doctrine to protect the contract "victim" and need not either, in the process, create complexity and uncertainty in the law. Unconscionability analysis assesses whole states of affairs. The process sends a clear signal to transactors that contractual exploitation will not be permitted, and if some indeterminacy in the case law remains, the benefits of the doctrine far outweigh it. ${ }^{144}$ Thus, the results attained by adoption of the unconscionability provisions of the UCC exemplify the advantages of this and similar standards that serve well the needs of society even though they cannot be applied with mathematical precision. ${ }^{145}$

141 Permanent Editorial BD. For THE UNIF. COMMERCIAL CODE, PEB STUdy Group UNIFORM COMMERCIAL CODE ARTICle 2: PRELIMINARY REPORT 9 (1990) (footnote omitted).

142 "When it is claimed or appears to the court that the contract or any clause thereof may be unconscionable the parties shall be afforded a reasonable opportunity to present evidence as to its commercial setting, purpose and effect to aid the court in making the determination." U.C.C. $\$ 2-302(2)$ (2009).

143 See, e.g., Ellinghaus, supra note 118, at 814-15 (describing unconscionability as "a residual category of shifting content," but concluding that "we cannot do without such regrettably vague standards').

144 For a further discussion of the benefits to be gained by putting legislation in the form of standards, see infra notes 175-214 and accompanying text.

145 One middle ground position might be to explicitly prohibit the use of specific types of provisions when used in certain types of contracts. See, e.g., Peter Linzer, "Implied," "Inferred," and "Imposed": Default Rules and Adhesion Contracts-the Need for Radical Surgery, 28 PACE L. REV. 195, 210-11 (2008) (explaining why "[w]e need rules, either court-made or legislative, that make specified clauses illegal and unenforceable in adhesion contracts"). It is perhaps not purely coincidental that the 
A similarly useful, if imprecise, standard is at work in the law of restitution, a doctrine-like unconscionability - with the potential to free courts from the convention or practice of strained characterization. ${ }^{146} \mathrm{~A}$ recent article by Professor James Rogers provides insight into the advantageous use of the unjust enrichment principle as an anti-manipulation doctrine. ${ }^{147}$ Rogers notes that as long as restitution is viewed as a parasitic doctrine (i.e., permitting recovery only when the conduct in question is characterized as wrongful by other law), ${ }^{148}$ courts will have an incentive to manipulate other law if existing legal categories of wrongful behavior do not quite fit. He contends, for example, that courts often find abuses of fiduciary relationships by defendants, even though such findings are hardly supported by applicable law. ${ }^{149} \mathrm{~A}$ better method would be to go right to the heart of the matter and simply determine whether it would be unjust for the defendant to gain from her behavior.

\section{B. The Law of Secured Transactions}

The improvement associated with moving from multiple sources of law to a single set of uniform rules has no better exemplar than the change wrought by Article 9 of the UCC. Prior to the Code, creditors faced a plethora of statutory and common law personal property security devices from which to choose. ${ }^{150}$ These included the pledge, ${ }^{151}$ chattel mortgage, ${ }^{152}$ condi-

Code does, in fact, prohibit particular types of clauses. See, e.g., U.C.C. § 4-103(a) (2009) (a bank may not "disclaim [its] responsibility for its lack of good faith or failure to exercise ordinary care"); id. $\S 7-204 \mathrm{cmt} .2$ (stating that a warehouse may not disclaim its obligation of due care).

146 For another UCC doctrine that has this same potential, see infra notes 240-59 and accompanying text.

147 See generally James Steven Rogers, Restitution for Wrongs and the Restatement (Third) of the Law of Restitution and Unjust Enrichment, 42 WAKE FOREST L. REV. 55 (2007).

148 Although Rogers suggests that the black-letter text of the proposed Restatement (Third) of Restitution and Unjust Enrichment is unclear on the question of whether recovery must be grounded in other law, see Rogers, supra note 147 , at 62 , he correctly points out that the official comments and reporter's notes leave little doubt that restitution and unjust enrichment were not intended to play an independent substantive role. $I d$. at 63 . For example, the official comment to section 44 reads as follows: "Restitution by the rule of this Section will sometimes yield a recovery where the claimant could not prove damages, but it does not create a cause of action where the claimant would otherwise have none." RESTATEMENT (ThIRD) OF RESTITUTION AND UNJUST ENRICHMENT $\S 44 \mathrm{cmt}$. a (Tentative Draft No. 4, 2005).

149 After discussing the English case of Reading v. Attorney-General, [1951] A.C. 507 (H.L.) (appeal taken from Engl.), in which a British army sergeant enriched himself by using his status to assist liquor smugglers, Rogers suggests that "[ $t$ ] he conclusion that [the British army sergeant] was or was not a 'fiduciary,' or that the conduct was or was not an 'abuse' of the fiduciary relationship, is likely to be added as a convenient way of categorizing the case rather than as the actual basis of decision." Rogers, supra note 147 , at 84 .

150 See Clayton P. Gillette \& Steven D. Walt, Uniformity and Diversity in Payment Systems, 83 CHI.-KENT L. REV. 499, 513 (2008). 
tional sale, ${ }^{153}$ trust receipt, ${ }^{154}$ assignment of accounts receivable, ${ }^{155}$ and factor's lien. ${ }^{156}$ It can be fairly said that as these various devices flourished, personal property security law became extraordinarily complex. One practitioner in the pre-Article 9 era described the state of the law as "a patchwork of odd devices that are replete with variations with little logical sense; gaps that are hard to fill; unnecessary duplications; and traps for the unwary."157

Article 9 accomplished a radical synthesis of the law. In one wave of the statutory wand, the system of independent security devices vanished and was replaced with the Article 9 security interest, a unitary personal property security device. ${ }^{158}$ The goal of the drafters had been to create one statutory umbrella that would cover all transactions in which obligations are secured by personal property. ${ }^{159}$ However, Article 9 does not ignore the particular features of the different types of personal property and transactional patterns. Rather, it includes special rules-rules applicable, however, only when needed to accommodate functionally relevant categories, and not on the basis of the type of security device selected by the parties (as was the case, for example, with the previous regime's chattel mortgage or conditional sale contract). One might sum up the success of Article 9 this way: "The important questions that remain relate, for the most part, to whether the maximum possible benefit has been gained from what most agree was a brilliant idea."160

151

152

153

154

155

156

157 Walter D. Malcolm, The Uniform Commercial Code as Enacted in Massachusetts, 13 Bus. LAW. 490, 505 (1958).

158 See GILMORE, supra note $151, \S 10.1$, at 295 ("The first thing to be noticed about Article 9 is its comprehensiveness: it is all-embracing, all-devouring; it covers everything.").

159 Original section 9-102(1) set forth the policy and scope of Article 9. In pertinent part, it read as follows:

[T]his Article applies so far as concerns any personal property within the jurisdiction of this State (a) to any transaction (regardless of its form) which is intended to create a security interest in personal property including goods, documents, instruments, chattel paper, accounts or contract rights; and also (b) to any financing sale of accounts, contract rights or chattel paper.

U.C.C. $\S 9-102(1)$ (1952). To send the clear message that the application of Article 9 was in no way dependent on the form of the transaction or the label used by the parties, subsection (2) stated: Among the transactions to which this Article applies are those in the form of pledge, assignment, chattel mortgage, chattel trust, trust deed, factor's lien, equipment trust, conditional sale, bailment-lease, trust receipt, other lien or title retention contract and a lease intended as security.

Id. $\$ 9-102(2)$.

160 E. Allan Farnsworth et al., Cases and Materials on Commercial Law 759 (5th ed. 1993). The discussion in the text is not meant to suggest that all complexity has been purged from the law of secured transactions. A current example of internal complexity was given earlier. See supra notes 


\section{The Law of Payment Systems}

Much of the contemporary discussion about regulation of the law of payment systems is reminiscent of that which preceded the adoption of UCC Article 9. As with Article 9, the debate is focused on whether different and sometimes inconsistent legal regimes applying to essentially the same conduct should be retained. ${ }^{161}$ Among the many factors that bear on accurate identification of governing payment rules are: (1) whether the payment involves a consumer; ${ }^{162}(2)$ whether the payment involves a debit transfer or credit transfer; ${ }^{163}$ (3) which particular wire transfer system or intermediary is used to process or collect the payment; ${ }^{164}$ and (4) whether

20-28 and accompanying text. Much of the external complexity stems from the interface of Article 9 and federal law. For example, Article 9 has always had an uneasy co-existence with federal statutes on copyrights, trademarks, and patents. See G. Larry Engle \& Mark F. Radcliffe, Intellectual Property Financing for High-Technology Companies, 19 UCC L.J. 3, 7-8 (1986). Indeed, the current law governing security interests in intellectual property rights is now so complicated that it has been described as "arguably dysfunctional." Alice Haemmerli, Insecurity Interests: Where Intellectual Property and Commercial Law Collide, 96 CoLuM. L. REV. 1645, 1649 (1996). Such legal complexities cannot possibly promote efficient markets or economic growth. See generally Raymond T. Nimmer, Revised Article 9 and Intellectual Property Asset Financing, 53 ME. L. REV. 287 (2001).

161 The same thing might be said about the current regulatory structure that regulates the many different types of financial services institutions based on non-functional distinctions. See Elizabeth F. Brown, The Tyranny of the Multitude Is a Multiplied Tyranny: Is the United States Financial Regulatory Structure Undermining U.S. Competitiveness?, 2 BROOK. J. CORP. FIN. \& COM. L. 369, 378 (2008) ("Numerous studies have identified the problem of overlapping regulatory authorities producing inconsistent regulations ...."). This has led the Department of the Treasury to propose a new classification system that emphasizes the importance of the function that each institution serves, thus greatly reducing the potential for overlapping and inconsistent regulations. See DEP'T OF THE TREASURY,

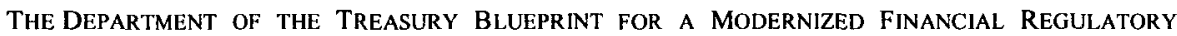
STRUCTURE 183 (2008), available at http://www.treas.gov/press/releases/reports/Blueprint.pdf.

162 The terms "retail payments" and "wholesale payments" are commonly used to denote whether the payment involves a consumer. The former do, whereas the latter do not. Significantly, only consumer electronic funds are governed by the Electronic Fund Transfer Act ("EFTA"), 15 U.S.C. §§ 1693a1693r (2006), and Regulation E, 12 C.F.R. pt. 205 (2009). See 15 U.S.C. § 1693(b) ("The primary objective of this subchapter . . is the provision of individual consumer rights."); 12 C.F.R. § 205.3(a) ("This part applies to any electronic fund transfer that authorizes a financial institution to debit or credit a consumer's account."). On the other hand, only wholesale funds transfers are covered by Article 4A. See U.C.C. $\S 4 A-108 \mathrm{cmt}$. (2009) ("Article 4A and EFTA [are] mutually exclusive."). Another source of law difference involves credit cards. The Truth in Lending Act, 15 U.S.C. $\S \S 1601-1615$, and Regulation Z, 12 C.F.R. pt. 226, are only applicable if the credit card user is a consumer. See, e.g., 12 C.F.R. $\$ 226.1$ (c) ("[T]his regulation applies [when] . . credit is offered or extended to consumers[.]").

163 A "debit transfer" is a funds transfer in which the instruction to pay is given by the person receiving payment. U.C.C. $\S 4 \mathrm{~A}-104 \mathrm{cmt} .4(2009)$. If the instruction to pay is given by the person making payment, it is called a "credit transfer." Id. Article $4 \mathrm{~A}$ is only applicable to credit transfers. Id.

164 For example, electronic funds transfers accomplished using a particular automated clearing house network are also subject to the rules of that network. See, e.g., id. \$4A-501 \& cmt. 1 (allowing "[f]unds-transfer system rule[s]," (e.g., clearing house rules) to vary the provisions of Article 4A (inter- 
the payment instrument is a paper check or has been converted into electronic information. ${ }^{165}$ The unfortunate consequences of all this payment law variation are not limited to the resulting legal complexity and confusion alone. ${ }^{166}$ They also include the significant and detrimental impairment of legal transparency. Quite often, for example, a payor will remain unaware of the payment system being used-and, hence, the source of law-until after she receives her bank statement. Such would be the case whenever a consumer mails a check to a creditor who has informed her only that the check may be used as a source document for an electronic check conversion. ${ }^{167}$

This source of law problem is not new; in fact, sporadic efforts to address it have been underway for decades. In the 1980s, for example, the ALI and ULC began a joint project to draft the Uniform New Payments Code, work that was based on the premise that "the new legal framework should not distort user choices among different payment systems, whether they be paper or card based, or electronic." 168 In the end, though, the new code was not to be. Not only was the drafting committee unable to reconcile the competing positions of the bank lobby and consumer groups, ${ }^{169}$ but, ironically, an argument grounded in complexity helped persuade the sponsoring organizations to abandon the project. In voicing its opposition to the effort to unify payments law, the New York Clearing House, after first asserting that no one would suggest integrating the law governing all forms of transportation systems, argued that:

Just as transportation systems move people or cargo, each payment system is, at bottom, a method for moving money from one place or person to another. Cash[,] . . bills and notes including checks, wholesale and retail electronic funds transfers, and credit cards, all

nal quotation marks omitted)). If another example is needed, it is worth noting that if a consumer funds transfer is made over Fedwire, the EFTA would not apply. 12 C.F.R. $\S 205.3$ (c)(3).

165 If a check given by a consumer is used as a source of information to make a one-time electronic debit to the consumer's bank account, the transaction is governed by the EFTA and Regulation E. See, e.g., 12 C.F.R. $\S 205.3$ (2). If an electronic system is used to collect the check after it is deposited with the depository bank, the sources of law include Articles 3 and 4 of the UCC, the Expedited Funds Availability Act, 12 U.S.C. $\S \S 4001-4010$, the Check Clearing for the 21 st Century Act, 12 U.S.C. $\S \S 5001-5018$, Regulation CC, 12 C.F.R. pt. 229, and, if a Federal Reserve Bank is used, Regulation J, 12 C.F.R. pt. 210.

166 Adding to the complexity and confusion are the growing number of new payment products. See generally Sarah Jane Hughes et al., Developments in the Law Concerning Stored-Value Cards and Other Electronic Payments Products, 63 BUS. LAW. 237 (2007).

167 When a check is provided, federal law requires that notice be given that information from the check may be used to make an electronic payment from the account indicated on the check. 12 C.F.R. $\S 205.3(\mathrm{~b})(2)(\mathrm{iii})$.

168 Memorandum from Professor Hal S. Scott, Reporter to the 3-4-8 Comm., to the Nat'l Conference of Comm'rs on Unif. State Laws 1 (June 15, 1983) (on file with the George Mason Law Review).

169 See, e.g., Gregory E. Maggs, New Payment Devices and General Principles of Payment Law, 72 NOTRE DAME L. REV. 753, 774-75 (1997). 
serve in primary part to effect this very simple function. While the issues that must be addressed in fashioning a law to govern each of these systems are very similar, each system works differently and the law should reflect those differences. Given the disparate nature of the transportation systems involved, attempts to combine them would necessarily lead to undue complexity. ${ }^{170}$

Still, the debate over unification of the law governing payment systems is not over, and perhaps the complexity and confusion currently associated with it will eventually be rectified. In 2008, the ULC issued a Position Paper recommending a "cooperative state and federal effort to provide a uniform and coherent statutory structure for all types and methods of payment."171 The financial services industry's response was swift and to the point:

\begin{abstract}
We strongly disagree with the various statements and opinions set forth in the Study Committee Report concerning the current state of payments law in the United States, and we are united in our opposition to any effort by the ULC to undertake a substantial revision or unification of the current U.S. payments laws either at the state or federal level. ${ }^{172}$
\end{abstract}

The ULC's response was to back down from its unification initiative. On March 16, 2009, a joint ULC/ALI Committee released a White Paper identifying "troublesome issues" under Articles 3 and 4 of the UCC and suggesting that a drafting committee might be formed to update these articles. ${ }^{173}$ Once again, the financial industry voiced its objection in a series of letters. ${ }^{174}$ What will be the outcome of all this wrangling? Only time will tell.

170 Peter A. Alces \& Marion W. Benfield, Jr, Cases, Problems, and Materials on PAYMENT SYSTEMS 3 (1993) (quoting N.Y. Clearing House, Statement on the Proposed Uniform New Payments Code 10, 11 (Sept. 29, 1983)) (internal quotation marks omitted).

171 Position Paper: Payment System Reform, UNIF. LAW CoMM'N, 8-9 (Mar. 2008), http://www.law.gonzaga.edu/centers-programs/Files/clc/Payment_System_Reform.pdf.

172 Banking Industry Pushes Back from Proposals by Uniform Law Commissioners to Modernize Payments Law via the UCC, Clarks' BANK Deposits \& PAYMEnTS MonThly, July 2009, at 1, 1 [hereinafter Banking Industry Pushes Back] (quoting Letter to the Uniform Law Commissioners (Dec. 17, 2008)) (internal quotation marks omitted) (discussing a letter from the "major players in the financial services industry").

173 Memorandum from Fred H. Miller, Chair, Study Comm. on Payments lssues, \& Linda J. Rusch, Reporter 1 (Mar. 16, 2009), available at http:/www.law.gonzaga.edu/centersprograms/Files/clc/white_paper_ucc_art_3_4.pdf; Banking Industry Pushes Back, supra note 172, at 2.

174 For example, the American Bankers Association stated that it did "not believe the issues and ambiguities outlined in the [ULC White Paper] are of a sufficient nature to justify the expense and time of a drafting project, especially when major stakeholders feel there is no compelling need for it . ..." See Banking Industry Pushes Back, supra note 172, at 3 (alteration in original) (internal quotation marks omitted). 


\section{STANDARDS AND REGIME UNIFICATION}

The examples in the previous Part illustrate that it is possible to avoid or reduce legal complexity and its costs. This Article now turns to a closer examination of the two proposed minimalist simplification strategiesadopting standards in lieu of rules and consolidating existing legal regimes - in order to assess their relative efficiency.

\section{A. Standards Versus Rules}

The exact form that legal criteria should take has attracted much attention among scholars. ${ }^{175} \mathrm{~A}$ fundamental issue examined in the resulting literature involves the relationship between rules and standards, as well as the questions of whether and when conduct or judicial decision making should be governed by one rather than the other. ${ }^{176}$ Perhaps the strongest objection to the use of standards in the commercial context is that standards are inherently unpredictable in their application and therefore add to the costs of transactions. ${ }^{177}$ The earlier discussion of unconscionability illustrates the problem. As seen in that context, the application of a statutory standard inevitably entails a delegation of discretionary authority to courts. The true meaning of a standard such as unconscionability becomes clear only through its application by a particular court. That application involves indi-

175 See, e.g., Ronald M. Dworkin, The Model of Rules, 35 U. CHI. L. REV. 14 (1967); Isaac Ehrlich \& Richard A. Posner, An Economic Analysis of Legal Rulemaking, 3 J. LEGAL STUD. 257 (1974); Louis Kaplow, Rules Versus Standards: An Economic Analysis, 42 DuKE L.J. 557 (1992); Duncan Kennedy, Form and Substance in Private Law Adjudication, 89 HARV. L. REV. 1685 (1976).

176 For these purposes, this Article will follow one useful definition of a standard as "a guide to conduct that announces the government's social or economic goals in regulating that conduct and that permits courts broad discretion in applying those goals directly in particular cases." Douglas G. Baird \& Robert Weisberg, Rules, Standards, and the Battle of the Forms: A Reassessment of $\$ 2-207,68$ VA. L. REV. $1217,1227-28$ (1982). On the other hand, a rule "is a very specifically framed guide to conduct that is detailed in its normative content and that the lawmaker believes will directly implement his social or economic goals." Id. at 1228 . Another way to view the difference between standards and rules is to focus on what is required for its application. The application of a rule requires no more than a determination of what did or did not happen-for example, did the customer notify its bank of an improper payment within one year after the statement or items were made available to the customer? See U.C.C. $\S 4-406(f)$ (2009). The application of a standard requires something more. Not only must the court engage in a determination of facts, it must take the added step of appraising what happened in terms of a statement of principle or policy-for example, did the buyer notify the seller of breach within a reasonable period of time? See id. §2-607(3)(a).

177 See, e.g., Kaplow, supra note 175, at 562-63 (noting that "standards are more costly for legal advisors to predict or enforcement authorities to apply because they require later determinations of the law's content"). Kaplow does point out, however, that over time, precedent will enhance the predictability of standards. Id. at 564 (suggesting that "a standard might be converted into a rule through the creation of a precedent"). 
vidualization of treatment reflecting the court's judgment as to the outcome that would best serve the underlying policy, objective, or principle associated with the standard. In fact, the drafters' fear that UCC section 2-302 would become a "joker running wild" led them to allocate decisional responsibility to the court as a matter of law. ${ }^{178}$ In any event, the need to resolve issues of unconscionability in disparate situations invariably involves an element of discretion, making the law less certain and increasing the cost of legal advice, both at the consultation and litigation stages.

It is argued that a rule-based system is more predictable and better able to constrain the undesirable exercise of discretion by decision makers; indeed, in certain limited situations, such a system may be preferable. However, the clear benefits of standards militate in favor of adopting them in many, if not most, situations.

First, standards make it easier for judges to be more candid and thorough in stating the reasons for their rulings, whereas a rules regime tends to obstruct such openness. The benefits of transparent decision making have already been noted and need not be repeated here, ${ }^{179}$ suffice it to say that there are many, and together with the corresponding costs of dissembling, they provide sufficient and convincing reasons to promote the judicial virtue of candor via the use of standards.

Second, the use of standards avoids the rigidity that often inheres in statutory commands. Standards permit change without the necessity of altering statutory commands, an attribute that contributes to the flexibility of the legal system and nurtures its ability to adapt to a changing society. ${ }^{180}$ The essential feature of a standard is that it is given content not by the legislature at the law's inception, but on a case-by-case basis by courts that have the opportunity to consider specific and varied fact patterns. For example, a hard-and-fast rule like that contained in UCC section 4-406, which mandates notice of the unauthorized signature or alteration of an instrument within one year, ${ }^{181}$ disables decision makers from permitting flexibility when mitigating factors in particular cases may justify overriding legislative judgment as to the sufficiency of a specific, set time period. In contrast, a standard of "reasonable notification" empowers the decision maker to consider specific circumstances, including conditions reflecting the evolution of commercial practice that might not have been contemplated at the law's enactment but nevertheless deserve recognition.

The necessity of assuring that statutory law remains responsive to a changing environment has long been recognized by lawmaking bodies. The original drafters of the UCC, for example, clearly understood that codifica-

\footnotetext{
178 See NEW YORK UCC STUDY, supra note 119, at 321 (internal quotation marks omitted).

179 See supra notes $116-49$ and accompanying text.

180 See Kaplow, supra note 175 , at 616 (observing that "[i]n the present legal system, it is usually believed that standards are easier to keep up-to-date").

181 See supra note 176.
} 
tion can fail because of the rigidity of statutory commands ${ }^{182}$ and designed the Code, from its inception, to be "a semi permanent piece of legislation." ${ }^{183}$ The drafters hoped it would be unnecessary to subject the Code to endless revision to keep it reflective of evolving social and economic conditions and that this job would instead fall within the bailiwick of an enlightened judiciary suitably armed with the necessary statutory tools to effect change. ${ }^{184}$ Notwithstanding the drafters' original intent, however, the Code has continued to thrive as the primary source of statutory commercial law only because of the willingness of the ULC and the ALI to revise and refine its provisions when necessary. ${ }^{185}$ This is a cumbersome, costly, and timeconsuming process, though, and one that could be minimized by a grant of interpretative authority to courts to take changed circumstances into consideration. A move from rules to standards would thus serve as a valuable, if partial, corrective to the problem of statutory obsolescence.

Interestingly, the historical concern of lawmakers that formal rules may obstruct legal progress was one justification for the approach taken by the drafters of Europe's nineteenth-century continental codes. For example, a classic articulation of the view that uncertainty about a changing future makes it normatively desirable that decision makers not be constrained by a rule is provided by the four jurists-Portalis, Tronchet, Bigot-Preameneu, and Maleville-who in 1800 prepared the first draft of what became the French Civil Code. They wrote:

To simplify everything, that is an operation on which one needs to agree. To foresee everything, that is a goal impossible of attainment.

182 This point is made by Grant Gilmore with considerable force:

[I]t is a matter of vital importance that the Code as a whole be kept in terms of such generality as to allow an easy and unrestrained application of its provisions to new patterns of business behavior. Commercial codification cannot successfully overparticularize: the penalty for being too precise is that the statute will have to keep coming in for repairs (and amendment is a costly, cumbersome, and unsatisfactory process) or else become a dead-letter.

Grant Gilmore, On the Difficulties of Codifying Commercial Law, 57 YALE L.J. 1341, 1355 (1948).

183 U.C.C. $\& 1-102 \mathrm{cmt} .1$ (1952).

184 The view that the judiciary would bear the principal responsibility for the accommodation of commercial law to existing economic and social realities is confirmed by the explicit direction of section 1-103. In particular, subsection (a) provides:

[The Uniform Commercial Code] must be liberally construed and applied to promote its underlying purposes and policies, which are: (1) to simplify, clarify, and modernize the law governing commercial transactions; (2) to permit the continued expansion of commercial practices, through custom, usage, and agreement of the parties; and (3) to make uniform the law among the various jurisdictions.

U.C.C. $\S 1-103(a)$ (2009) (alteration in original). We are told in comment 1 to this section that its purpose is "to make it possible for the law embodied in the Uniform Commercial Code to be applied by the courts in the light of unforeseen and new circumstances and practices." Id. $\$ 1-103$ (a) cmt. 1

185 See Agreement Describing the Relationship of the American Law Institute, The National Conference of Commissioners on Uniform State Laws, and the Permanent Editorial Board with Respect to the Uniform Commercial Code, 64 A.L.I. Proc. 769, 770 (1987) (discussing the need to revise the Code when necessary). 
A code, however complete it may appear, is no sooner promulgated than a thousand unexpected questions are presented to the judge. Because the laws, once written, remain as they were written. Man, on the contrary, never remains the same, he changes constantly; and this change, which never stops, and the effects of which are so diversely modified by circumstances, produces at every instant some new combination, some new fact, some new result.

The function of the law (loi) is to fix, in broad outline, the general maxims of justice (droit), to establish principles rich in suggestiveness (conséquences), and not to descend into the details of the questions that can arise in each subject.

It is for the judge and for the lawyer, embodied with the general spirit of the laws, to direct their application. ${ }^{186}$

Most importantly, the rigidity of rules may function as an impediment to a decision maker's ability to render a just result in a particular case. ${ }^{187}$ Take, for example, a case in which a plaintiff succeeds in proving the formation of a valid and enforceable contract for the sale of goods, but cannot satisfy the statute of frauds provisions of UCC section 2-201. If the plaintiff can prove that she relied on the contract and that her reliance was substantial, should the ritualistic formalities of the statute of frauds really be permitted to defeat her claim? Most courts would deem such a claim to be just, and they might even regard the defendant's reliance on the rigidity of the statute as, in a sense, the perpetration of a fraud-an ironic application of a law enacted with the clear purpose of policing against fraud. For this reason, some courts have resorted to the doctrine of promissory estoppel to prevent "unconscionable injury" to the plaintiff. ${ }^{188}$ Others, however, have not been willing to depart from the strictures of the statute. ${ }^{189}$ Although the issue in

186 Portalis, Tronchet, Bigot-Prémeneu \& Maleville, Discours préliminaire, in $1 \mathrm{~J}$. LOCRÉ, LA LÉGISLATION CIVILE, COMMERCIALE ET CRIMINELLE DE LA FRANCE 251, 255-72 (1827), reprinted and translated in ARTHUR TAYLOR VON MEHREN \& JAMES RUSSELl GORDLEY, THE CIVIL LAW SYSTEM 54, 54 (2d ed. 1977).

187 See Frederick Schauer, Formalism, 97 YALE L.J. 509, 539 (1988) (emphasizing that "[i]nsofar as factors screened from consideration by a rule might in a particular case turn out to be those necessary to reach a just result, rules stand in the way of justice in those cases and thus impede optimal justice in the long term"). This Article's assumption is that most people would agree that one aim of statutory law is the attainment of justice. One problem with such a statement is, of course, that it would be surprising if everyone were to agree on the same meaning of "justice." The term is used here in the non-technical and emotive sense of being treated in a way that a majority of people would think is fair.

188 See, e.g., Allied Grape Growers v. Bronco Wine Co., 249 Cal. Rptr. 872, 878 (Ct. App. 1988) ("Unconscionable injury results from denying enforcement of a contract after one party is induced by another party to seriously change position relying upon the oral agreement. It also occurs in cases of unjust enrichment.").

189 For cases that have been unreceptive, see, e,g., McDabco, Inc. v. Chet Adams Co., 548 F. Supp. 456, 460 (D.S.C. 1982) (explaining that under South Carolina law, promissory estoppel cannot be used to circumvent the statute of frauds); Lige Dickson Co. v. Union Oil Co. of Cal., 635 P.2d 103, 107 (Wash. 1981) (en banc) (noting that "increased litigation and confusion" would necessarily result if promissory estoppel were allowed to overcome valid statute of frauds defense). Although promissory estoppel is the most frequently asserted non-statutory exception, there is authority supportive of others. 
these cases is typically framed in terms of the drafters' intent, ${ }^{190}$ at its core, the real issue is whether section 2-201 should be interpreted in a manner that would allow its rules to trump the normative power of its purposes. Section 2-201 would become an obstacle to its own intended function if applied so as to restrict the scope of the decision maker's inquiry based on narrow interpretations of the section's express language. Such rigid application, even in the face of facts that would dictate a result counter to the underlying purposes of the statute, cannot be supported. Since this continues to occur, a reframing of the section in the less precise terms associated with a standard would more efficiently and consistently result in just outcomes.

Third, it is not always feasible for lawmakers to successfully draft legislation with the precision of rules, ${ }^{191}$ a problem of which Karl Llewellyn was doubtless aware as he engaged in the drafting of UCC Article 2. Because Article 2 would be applicable in commercial settings that varied substantially from one another, Llewellyn knew that it would ultimately be up to the courts to divine and fulfill the parties' expectations on the basis of their factual bargains. ${ }^{192} \mathrm{He}$ therefore built the foundation for much of Ar-

See, e.g., H.B. Alexander \& Son, Inc. v. Miracle Recreation Equip. Co., 460 A.2d 343, 345 (Pa. Super. Ct. 1983) (holding that the statute of frauds was waived through course of dealing and conduct).

190 The statutory issue is whether section 2-201 displaces non-Code principles otherwise preserved in section 1-103(b). That section provides:

Unless displaced by the particular provisions of [the Uniform Commercial Code], the principles of law and equity, including the law merchant and the law relative to capacity to contract, principal and agent, estoppel, fraud, misrepresentation, duress, coercion, mistake, bankruptcy, and other validating or invalidating cause supplement its provisions.

U.C.C. $\S 1-103$ (b) (2009) (alteration in original).

191 Kaplow notes that "some legal commands cannot plausibly be formulated as rules. For example, it may not be possible to specify in a zoning ordinance which building designs are aesthetically inappropriate, but we may know them when we see them." Kaplow, supra note 175, at 599-600. Kraakman and Hansmann make this same point in the context of corporate governance:

By contrast, few jurisdictions rely solely on the rules strategy for regulating complex, intra-corporate relations, such as, for example, self-dealing transactions initiated by controlling shareholders. Such matters are, presumably, too complex to regulate with no more than a matrix of prohibitions and exemptions, which would threaten to codify loopholes and create pointless rigidities. Rather than rule-based regulation, then, intra-corporate topics such as insider self-dealing tend to be governed by open standards that leave discretion for adjudicators to determine ex post whether violations have occurred.

John Armour, Henry Hansmann \& Reinier Kraakman, Agency Problems and Legal Strategies, in The ANATOMy OF CORPORATE LAW: A COMPARATIVE AND FUNCTIONAL APPROACH 35, 39-40 (Reinier Kraakman et al. eds., 2 d ed. 2009).

192 Keep in mind that Article 2 captures within its scope transactions in goods as diverse as cattle and gas, and it applies regardless of whether the parties are sophisticated merchants or unsophisticated consumers. It would be absurd to believe in the possibility of producing one set of uniform rules that would work well in each of the many diverse transactions that may take place. It would no doubt be inefficient and lead to confusion if the attempt were made to draft tailor-made rules for each of the possible transaction categories. Hirsch makes a similar point using the federal tax code:

We find that historically legislatures have had great difficulty in writing tax legislation. The reasons are that very great diversity and complexity surrounds the conditions under which incomes are earned, and that legislatures seek to pursue a large variety of income tax objec- 
ticle 2 on the concept of "agreement." The definition provides: "Agreement,' . . means the bargain of the parties in fact, as found in their language or inferred from other circumstances, including course of performance, course of dealing, or usage of trade . . .." Comment 1 to section 1-303 further reinforces this notion of commercial expectations that develop in the context of actual practices:

\begin{abstract}
The [Code] rejects both the "lay-dictionary" and the "conveyancer's" reading of a commercial agreement. Instead the meaning of the agreement of the parties is to be determined by the language used by them and by their action, read and interpreted in the light of commercial practices and other surrounding circumstances. The measure and background for interpretation are set by the commercial context, which may explain and supplement even the language of a formal or final writing. ${ }^{194}$
\end{abstract}

Moreover, when the parties have neglected to resolve certain essential aspects of their bargain for themselves, the Code fills these gaps with openended standards rather than rules. ${ }^{195}$ In sum, Article 2 is best understood and defended as a means of facilitating common law decision making, ${ }^{196}$ and its success is a testament to the power of adaptable standards.

Lastly, and perhaps most fundamentally, standards are easier and less costly to draft. Rule writing requires that legislators expend significant amounts of time and effort in identifying numerous contingencies that might occur and in describing and dealing with each in language as precise as possible. This makes for a protracted and expensive legislative process. Standards significantly reduce these costs by allowing decision makers to essentially create the nuances of commercial law on an ex post basis and in so doing, tailor them not merely to the prognostications of legislators, but to circumstances that have actually occurred. Particularly when the frequency of covered cases is anticipated to be relatively low, using standards to eliminate the need for legislators to foresee and address every possible contingency would best serve both efficiency and cost effectiveness.

Certainly, rules may better regulate behavior in some aspects of commercial life; possibly even in the commercial law system generally. Yet it is

\footnotetext{
tives. As a result, the Internal Revenue Code has some 1,856 pages relating solely to federal income taxes which are supplemented by over 4,000 pages of Treasury regulations.

Hirsch, supra note 95 , at 1240 n.15.

193 U.C.C. $\$ 1-201(\mathrm{~b})(3)(2009)$.

194 Id. $\S 1-303 \mathrm{cmt} .1$.

195 See, e.g., U.C.C. $\S 2-305$ (1) (2009) (explaining that if the parties have not agreed on price, "the price is a reasonable price"); $i d . \S 2-309(1)$ (stating that " $[t]$ he time for shipment or delivery or any other action under a contract if not provided in this Article or agreed upon shall be a reasonable time").

196 Notice that when Article 9 attempts to regulate heterogeneous behavior, as it does in Part 6, it does so in a style similar to the approach taken in Article 2. See, e.g., Donald J. Rapson, Repurchase (of Collateral?) Agreements and the Larger Issue of Deficiency Actions: What Does Section 9-504(5) Mean?, 29 IDAHO L. REV. 649, 680-92 (1993) (criticizing the application of the "commercial reasonableness" standard when applied in the context of deficiency actions (internal quotation marks omitted)).
} 
a mistake to assume that the entire system need be designed according to such a model just because it is effective in some instances. Rather, rules and standards ought to be seen as complementary tools, each to be used when most likely to further the fundamental purposes and principles of the law in the most economical and advantageous manner.

The greatest theoretical difficulty for those who advocate the use of standards is the indeterminacy associated with outcomes that cannot be easily predicted by commercial transactors and the lawyers who advise them. However, empirical evidence suggests that determinacy in the sense of unequivocal exactness about the requirements of the law may be less relevant in governing the day-to-day commercial practices of parties than one might guess. As expressed by Professor Stewart Macaulay in his wellknown and often-cited article:

\begin{abstract}
Contract planning and contract law, at best, stand at the margin of important long-term continuing business relations. Business people often do not plan, exhibit great care in drafting contracts, pay much attention to those that lawyers carefully draft, or honor a legal approach to business relationships. There are business cultures defining the risks assumed in bargains, and what should be done when things go wrong. People perform disadvantageous contracts today because often this gains credit that they can draw on in the future. People often renegotiate deals that have tumed out badly for one or both sides. They recognize a range of excuses much broader than those accepted in most legal systems. ${ }^{197}$
\end{abstract}

Thus, while perhaps counterintuitive, it nevertheless seems a valid conclusion that given the observed dichotomy between commercial law and commercial practice, there is scant reason to be overly concerned about the indeterminacy of standards. The countervailing notion, of course, is that a model of lawmaking under which standards predominate would contradict the deeply felt, widely held, and beneficial belief that the content of commercial law does matter. While some may admit acting without concern for the legal consequences of their actions, the same is not true for those who seek the assistance of legal counsel. ${ }^{198}$ Llewellyn himself recognized the

197 Stewart Macaulay, An Empirical View of Contract, 1985 WIS. L. REV. 465, 467-68. Macaulay's conclusion is supported by other studies. See Russell J. Weintraub, A Survey of Contract Practice and Policy, 1992 WIS. L. REv. 1, 5 (suggesting that "it is a delusion to assume that commercial conduct is primarily controlled by what is 'legal"'); James J. White, Contract Law in Modern Commercial Transactions, an Artifact of Twentieth Century Business Life?, 22 WASHBURN L.J. 1, 1, 19 (1982) (conducting an empirical study of chemical and pharmaceutical companies and offering the "thesis that contract law is a much less significant determinant of commercial behavior in complex transactions than the typical law student, contracts professor, or lawyer dares believe").

198 An alternative hypothesis for why there might be less reliance on existing law than one might assume posits that even a moderately well-educated layman is incapable of understanding its content. This is particularly the case with a complex statute like the UCC. It should be emphasized that each Code provision is part of a comprehensive commercial law system consisting not only of the various sections within an article and the several articles, but also of domestic common law and statutes external to the Code. Seen this way, commercial law has certain characteristics of orderliness, systemic and interrelated rules, and a precise, consistent terminology that gives it a rational structure. In fact, it is for 
existence of "counselor's rules"-rules that, perhaps exclusively from the counselor's perspective, can be perceived as having shaped the transaction. These, noted Llewellyn, are "solid, settled, clear rules on which he can build; they are safe, they are bedrock." 199 Yet should the ease and comfort made available to commercial law attorneys by "bedrock rules" drive the mix of rules and standards included in the law? This approach might make sense if predictability were all that mattered, but we have seen that other equally vital considerations exist. ${ }^{200}$

Yet another advantage of the use of standards can be seen by examining the creation and subsequent back-end costs of enforcing contract terms. A number of legal scholars have focused on the choices made by contracting parties when they elect to include in their agreements either vague terms (standards) or precise terms (rules). ${ }^{201}$ The contracting relationship is particularly interesting because, unlike the legislative process, it is not beset by the problems associated with collective decision making and interest group pressures. Rather, it involves only the parties who desire to tailor their agreement so that it will best serve their own particular purposes. ${ }^{202}$ Paral-

this reason that the original drafters were comfortable leaving gaps to be filled by a considerable body of case law. See U.C.C. $\$ 1-103(b)$ (2009). The New York Law Revision Commission, writing in a far less legally complex era, summed it up this way:

Will our hypothetical Mr. Businessman derive enlightenment from any of the provisions of the Code unless he has mastered the whole complicated system of definitions and crossreferences? In this connection, it does not matter whether one or the other section of the Code might be made clearer by improved draftsmanship. The important point is that the subject matter of the Code, in this country and at this time, is too complex for any restatement or codification in terms which the nonexpert will understand. To recognize this, does not mean to condemn the idea of codification, but to gain proper perspective for appraising this particular Code. If we realize that the Code is a tool for lawyers, and for lawyers only, then we begin to see that ... the Code makes the law more "knowable" only to the extent that it facilitates the work of professional experts.

NEW YORK UCC STUDY, supra note 119, at 92-93.

199 K. N. Llewellyn, The Modern Approach to Counselling and Advocacy-Especially in Commercial Transactions, 46 COLUM. L. REV. 167, 168 (1946).

200 See supra notes $163-83$ and accompanying text.

201 For important contributions, see generally Luca Anderlini \& Leonardo Felli, Incomplete Written Contracts: Undescribable States of Nature, 109 Q.J. ECON. 1085 (1994); Pierpaolo Battigalli \& Giovanni Maggi, Rigidity, Discretion, and the Costs of Writing Contracts, 92 AM. ECON. REV. 798 (2002); B. Douglas Bernheim \& Michael D. Whinston, Incomplete Contracts and Strategic Ambiguity, 88 AM. ECON. ReV. 902 (1998); Robert E. Scott \& George G. Triantis, Anticipating Litigation in Contract Design, 115 YALE L.J. 814 (2006); George G. Triantis, The Efficiency of Vague Contract Terms: A Response to the Schwartz-Scott Theory of U.C.C. Article 2, 62 LA. L. REV. 1065 (2002).

202 See Scott \& Triantis, supra note 201, at 820 (positing that this difference between legislation and contracts accounts for the fact that "we can be more confident that the parties will agree to an efficient mix of rules and standards in their contract"). Scott, in another article, takes account of the forces that shape revisions of the commercial law and notes the relationship between those forces and the tenor of the resulting codification. See Robert E. Scott, The Politics of Article 9, 80 VA. L. REV. 1783 (1994). He suggests, for example, that special interests dominate uniform commercial law revision because the process lacks the system of checks and balances provided by public legislatures. Revision efforts, there- 
lels between statutory and contractual outcomes generate a number of interesting insights. In both realms, the question is whether costs should be incurred at the front end in an attempt to foresee and address numerous future contingencies or at the back end, only if and when a dispute materializes. ${ }^{203}$

The contracts literature suggests two essential categories of back-end enforcement costs that might motivate parties to eschew vague contractual terms. These are the direct costs of evidence production ${ }^{204}$ and the uncertainty of result, including the risk that courts might err in deciding cases. ${ }^{205}$ Having identified these potential costs, some contracts theorists have suggested that parties will attempt to avoid them by including precise rather than vague terms in their agreements. ${ }^{206}$ As Professors Robert Scott and George Triantis observe, however, this has simply not proven to be the case. Their review of 24,965 contracts contained in the University of Missouri (Columbia) contracts library found that 4,328 contracts contained the vague term "best efforts," 38 contracts used the term "reasonably withheld," 3,525 relied on the term "unreasonably withheld," and a whopping 13,281 contracts employed the classically vague term "reasonable." ${ }^{207}$ Identifying and analyzing a combination of strategies available to contracting parties, Scott and Triantis have been able to discern the rationale for this

fore, develop commercial law that serves those special interests at the expense of constituencies impotent to protect their rights:

Because Article 9 regulates asset-based financers, a paradigmatic example of well-organized and cohesive interests, the process is susceptible to disproportionate influence by a single active interest group representing particular financing interests. In such a case, I suggest that the law revision process will tend to propose rules that are both transactionally efficient and distributionally favorable to the dominating interests.

Id. at 1850 . On the other hand, Scott and Alan Schwartz suggest that vague standards appear in Article 2 because the drafting process was dominated by academics that believed a rule-based statute would be more difficult to get the states to adopt. Alan Schwartz \& Robert E. Scoth, The Political Economy of Private Legislatures, 143 U. PA. L. REV. 595, 646 (1995) ("Because academics were and are in charge, we predict that both the original Article 2 and the revisions will contain many vague rules. The former prediction is confirmed on the face of the statute. Almost everyone who has studied the subject agrees that the original Article 2 has many [vague] rules.").

203 In terms of who supplies the content to contractual legal obligations, the difference between precise terms (i.e., rules) and vague terms (i.e., standards) is that the parties perform the task with the former and the court performs the task with the latter.

204 Scott and Triantis point out that the parties must incur the costs of establishing what evidentiary proxies should be used to determine whether the standard has been met, the weight to be given to each proxy, and the facts that support or do not support the presence of the proxies. See Scott \& Triantis, supra note 201 , at 826 . For example, if a contractor were required to construct a "sturdy wall," there would have to be evidence of what requirements have to be met to have a sturdy wall and then evidence that these requirements were or were not met. If the parties wish to incur the up-front contracting costs of doing so, they could decide for themselves the relevant proxies for a determination of whether the wall is sturdy. Then, the court need only decide whether those proxies have been satisfied.

205 Id. at 831-32.

206 See, e.g., Oliver Hart, Firms, Contracts, ANd Financial Structure 21-28 (1995); BERNARD SALANIE, THE ECONOMICS OF CONTRACTS 175-89 (1997).

207 Scott \& Triantis, supra note 201, at 824 n.21 (internal quotation marks omitted). 
somewhat puzzling preponderance of vague contract terms. In their view, the explanation is that vague terms are often best suited to solve the twin problems endemic to contracts; namely, the need to provide proper incentives to perform and the need to allow the parties to invest only when it is efficient to do so.

In Scott and Triantis's terminology, parties reduce contracting costs by making themselves the "choosers" of the appropriate performance proxies (i.e., rules) whenever the private information they possess is complete enough to assure the accuracy of their choice of performance measures. Conversely, parties delegate the job of "chooser" to the court at the back end when the performance proxies are less amenable to predefinition and more likely to be influenced by changing circumstances. ${ }^{208}$ In other words, the relative usefulness of hindsight plays an important role in the parties' selection of vague or precise terms. When information already possessed by the contracting parties at the time they construct their agreement permits the inclusion of specific performance criteria, contract terms take the form of rules. In the absence of such sufficient private information, or when lateridentified facts and circumstances can best determine whether a party has substantially performed, contract terms take the form of standards to be applied by the court. ${ }^{209}$ Another insight central to the Scott and Triantis thesis is that when vague terms are used, the estimated costs of enforcement might be overstated (e.g., when the parties avoid most costs by renegotiating their agreement or settling their dispute) $)^{210}$ or subject to reduction (e.g., by the use of alternative dispute resolution mechanisms or contractual allocations of burdens and standards of proof). ${ }^{211}$

If the foregoing analysis is generally correct, the coexistence of vague terms with precise terms in commercial contracting practice would enhance, rather than detract, from the likelihood of contracting gains. Likewise, the utility of contracts would be strengthened by the inclusion of statutory standards as defaults when knowledgeable parties deem them to be superior to precise terms that could otherwise be included in their agreements. In the UCC framework, default provisions reduce contract formation costs by enabling the substitution of a so-called "hypothetical bargain" for a nonexistent real one. That is, if it is clear that the parties intended to contract

\footnotetext{
208 Id. at $840-44$.

209 To illustrate their point, Scott and Triantis borrow from the work of Canice Prendergast, The Provision of Incentives in Firms, 37 J. ECON. LITERATURE 7, 22 (1999). They use as their example baseball contracts, where it is uncommon to find provisions that provide bonuses for specific performance aspects such as hitting home runs. Typically, a holistic measure of performance, say, making the all-star team is used instead. Why? Because an ex ante determination of proxies is simply not feasible. Depending on the course of the season, the game, etc., attempting a home run may or may not be important. Hence, the proxy choice is delegated after the fact to a third-party decision maker. Scott \& Triantis, supra note 201 , at 846 .

210 Scott \& Triantis, supra note 201 , at 819.

211 Id. at 866-69.
} 
but they have failed to include a term essential to the determination of their rights and duties, the default provision fills the gap with a term that the parties would likely have agreed to had they considered and negotiated the matter. ${ }^{212}$

As has been seen, while some commentators have regarded legal rules as superior to complex standards, ${ }^{213}$ this view is not always warranted and is not consistently borne out by contracting parties. By incorporating such concepts as commercial reasonableness and good faith in the UCC in a manner that parallels the actual practices of contracting parties, the drafters purposefully designed it-particularly, for example, in Article 2-so that the "rule of law" has meaning only by reference to the particular setting and circumstances within which the commercial transactors do business. The court's role in this schema, as where contracting parties have deliberately chosen vague standards of performance over precise criteria, is not to apply rules laid down in advance, but to recognize and uphold the validity of commercial norms. Those who reject the suitability of standards may justify their position on the notion that the protection of rational expectations and the promotion of reliance is crucial to commercial law. Perhaps, then, the biggest challenge in deciding whether legal commands should be expressed as rules or standards lies in clearly distinguishing those commands that can be characterized as bedrock rules-and thus relied on invariably-from those that cannot--and which can therefore be expected to be applied based on particular facts and circumstances. More than mere classification is required, though; each bedrock rule should be re-examined to discern whether it could optimally be replaced by a standard when all costs and benefits are taken into account. Thus, the process of selecting a rule or standard in each instance must entail consideration by the lawmaking institution of a combination of factors, which should not necessarily be given equal weight in every case and which should be evaluated in the context of the specific subject matter of the statutory command. This Article will later demonstrate the

212 See, e.g., Frank H. Easterbrook \& Daniel R. Fischel, The Corporate Contract, 89 ColuM. L. REV. 1416, 1433 (1989) (stating that the default term should be "the term that the parties would have selected with full information and costless contracting"); Charles J. Goetz \& Robert E. Scott, The Mitigation Principle: Toward a General Theory of Contractual Obligation, 69 VA. L. REv. 967,971 (1983) (explaining that "the preformulated rules supplied by the state should mimic the agreements contracting parties would reach were they costlessly to bargain out each detail of the transaction"); Alan Schwartz, Proposals for Products Liability Reform: A Theoretical Synthesis, 97 YALE L.J. 353, 361 (1988) (stating that the default rule should reflect "the contract that most well-informed persons would have adopted if they were to bargain about the matter").

213 For example, not everyone believes that the drafting style of Article 2 is the correct one. See, e.g., Richard Danzig, A Comment on the Jurisprudence of the Uniform Commercial Code, 27 STAN. L. REV. 621, 630 (1975) ("[T] Le Llewellyn approach seems paradoxically to undermine that very certainty and consistency in the law that the Uniform Commercial Code was dedicated to obtaining."). 
application of this proposed framework in a context in which rules and a standard presently coexist and compete. ${ }^{214}$

\section{B. Regime Unification}

A legislature can achieve regime unification as a means of legal simplification in a variety of ways. To begin with, there is the possibility that a legislature can bring about complete uniformity in the source of law by enacting a single statute that brings together virtually all the rules governing a particular subject area. Perhaps the best example of such an accomplishment is Article 9 of the Code. ${ }^{215}$ As Article 9 has demonstrated, combining several sources of law alleviates much of the uncertainty over the rules that govern a particular transaction by eliminating the problem of external complexity. It also correspondingly increases the efficiency of transactions by decreasing learning costs for those who would otherwise be forced to navigate a sea of statutes. Moreover, a one-statute system makes it easier for the responsible lawmaking body to make helpful improvements to the law because only one revisionist effort is needed to keep pace with social changes. ${ }^{216}$

There is, however, a potential benefit to instead adopting or retaining a multi-statute system, and this should not be ignored. If one views each source of law as providing parties with a choice of defaults for use when essential contract terms have been omitted, then the availability of multiple competing statutes provides the parties with additional flexibility: they can choose the set of statutory defaults that bests approximates the provisions they would have included in their contract had they negotiated the matter. Thus, while a one-statute system may represent the triumph of simplicity over complexity and confusion, it comes at the cost of some efficiency associated with having more than one choice of defaults-and while parties could always contract out of statutory defaults, they would have to incur the alternate costs associated with doing so.

In this connection, a recent article by Professors Clayton Gillette and Steven Walt provides an important contribution. ${ }^{217}$ In endeavoring to support their opposition to a unitary payments code that would create one set of rules for all kinds of transactions, Gillette and Walt reject the notion that Article 9 is an apt analogy. In their view, a single set of rules works well in

214 See infra notes 228-59 and accompanying text.

215 For a discussion of what Article 9 accomplished, see supra notes 150-60 and accompanying text.

216 A related benefit would be that the application of case law would not be confined to just one of several statutes. This avoids the necessity of having to decide the same issue over and over in different statutory contexts and allows for clarifying interpretations to proceed more rapidly.

217 See Gillette \& Walt, supra note 150. 
the Article 9 context because it governs the activities of creditors who are similarly situated in terms of their abilities to make use of information gleaned from the UCC filing system and to monitor their debtors' activities. ${ }^{218}$ This, Gillette and Walt assert, is not the case with users of the various forms of payment systems, who differ significantly in characteristics and preferences ${ }^{219}$ and whose range of transactions lacks the uniformity of transactions involving secured credit. ${ }^{220}$ Thus, Gillette and Walt conclude that uniform majoritarian defaults are not feasible with respect to payment systems. As a consequence, they suggest that transactors would be better served by having access to various payment statutes, each with its own unique set of default rules for allocating risks in a manner acceptable to the parties. 221

Gillette and Walt's perceived distinction between the law of secured transactions and payment law fuels their opposition to regime unification as a consistent means of reducing the internal and external complexities of commercial law. However, their premise bears further examination, as this view seems to overlook the nature of Article 9. ${ }^{222}$ That is, Article 9 is not a statute purporting to contain one set of rules cutting across and applying to all types of secured transactions. Rather, its function is to collect in one statute rules that do vary along functional lines when necessary. This ap-

218 Id. at 514 ("Simply put, Article 9 governs transactions involving creditors within a fairly predictable range of abilities to provide and make use of information, and to monitor particular assets of the debtor.").

219 Id. at 515-16 ("Payment system users range in their sophistication about the rules and consequences of the form of payment they use; in addition, this sophistication varies between consumers, sole proprietors, and small businesses.").

220 Id. at 515 (observing that "[s]ome payment systems typically involve two parties, some involve three parties, some--but not all-implicate multiple repeat players, some--but not all-involve sophisticated risk-reducing technology").

221 Id. at 515-16.

222 There are several difficulties. One difficulty is their assumption that the availability of secured credit enables the debtor to reduce its total credit costs by issuing priority secured debt to the creditor who is in the best position to monitor the debtor's assets. Where is the empirical evidence that total costs are, in fact, reduced, or even that secured creditors engage in serious monitoring efforts that affect the debtor's behavior? There is, however, empirical evidence to support a contrary assumption. See, e.g., Lucian Arye Bebchuck \& Jesse M. Fried, The Uneasy Case for the Priority of Secured Claims in Bankruptcy, 105 YALE L.J. 857, 934 (1996) (demonstrating that the priority of secured creditors "causes excessive use of security interests, reduces the incentive of firms to take adequate precautions and choose appropriate investments, and distorts the monitoring arrangements chosen by firms and their creditors"). Another difficulty is the view that secured transactions share a commonality of parties and characteristics that payment transactions do not. This begs the question: How can they say this when creditors differ (e.g., commercial lenders, trade creditors, and creditors who sell and lend to consumers), the nature of the underlying debt differs (e.g., antecedent debt and new money loans), and the fact that Article 9 even applies to purchase and sale of notes, chattel paper, accounts and payment intangibles? See U.C.C. § 9-109(a)(3) (2009). Finally, they ignore the possibility that payment systems will often merge. For example, a check is subsequently converted to an ACH transaction. See supra note 168 and accompanying text. 
proach at least minimizes internal complexity in the law of secured transactions and, in addition, very effectively eliminates the external complexity of the predecessor regimes. ${ }^{223}$ This Article would submit that Article 9 should not be so readily dismissed as a model of beneficial change that could be applied with equal effectiveness in the realm of payment systems.

A variant of the single-statute strategy meriting consideration is a "hub and spoke" approach to structuring a set of related statutes. Although ultimately rejected by the UCC Article 2 drafting committee as a method of bringing software contracts into the article's scope, ${ }^{224}$ the Code itself is structured in this manner. ${ }^{225}$ Furthermore, the idea has gained traction elsewhere. For example, a drafting committee of the Alabama Law Institute recently completed a project that radically reorganizes the state's business entity laws using a hub-and-spoke organizational scheme similar to that of the UCC. ${ }^{226}$ Article 1 of the business entities statute, constituting the hub, consists of provisions equally applicable to all of the various types of business entities. Each remaining article, linked to the hub as a spoke, applies only to one of the particular entity types. The inevitable challenges inherent in identifying the content of the hub and of each spoke may require a substantial amount of effort, but in the end, it eliminates a great deal of statutory confusion and significantly reduces both internal and external complexity. ${ }^{227}$

Even if complete statutory consolidation is not conceptually possible in a given area of law, it is unlikely that insurmountable obstacles to uniformity among specific rules within each statutory alternative exist, as long as the underlying policy positions of the various rules are identical. While rule uniformity, regardless of the particular statute in which the rules might be lodged, is not a panacea, it is a simplification strategy that remains beneficial. Transactors may continue to have some difficulty determining which statutory set of rules actually governs particular disputes, but the costs of being mistaken will be lessened, and in many cases, the choice simply will not matter in the final analysis.

\footnotetext{
223 See supra notes $150-60$ and accompanying text.

224 See supra notes $11-18$ and accompanying text.

225 Article 1 ("General Provisions") of the Code, with its definitions and fundamental principles of commercial law, can be viewed as a "hub." From this hub emanates the other articles or "spokes." See supra note 11 and accompanying text. Each article covers a different sort of transaction, but they have enough in common to justify the application of the same hub provisions. See, e.g., U.C.C. § 1-102 (2009).

226 Current 2009 Projects, ALA. LAW INST., http://ali.state.al.us/projects.html (last visited Nov. 15, 2010 ).

227 The Alabama Law Institute thought that the unification of business entity legislation was worth a nine-year drafting effort with over fifty meetings at a cost of over $\$ 2$ million of donated legal services. Id.
} 


\section{OPPORTUNITIES TO REDUCE COMPLEXITY: Two SUGGESTIONS}

\section{A. Suggestion One: The Classification and Measurement of Damages Under the Code}

UCC Article 2 sets forth the ground rules by which aggrieved parties-both sellers and buyers-may recover damages for breach. These ground rules are stated in terms of both the classification and measurement of damages. On the classification side, the Code draws substantive distinctions among general, incidental, consequential, and punitive damages. The classification matters to sellers because they are generally allowed, under Code section 1-305, to recover only general and incidental damages, but not consequential or punitive damages. Section 1-305 requires construction of remedial provisions so as to place the aggrieved party in the position it would have attained had the breaching party fully performed, but it further provides that "neither consequential or special damages nor penal damages may be had except as specifically provided in [the Uniform Commercial Code] or by other rule of law." 228 The comment states that the purpose is to make clear that "compensatory damages are limited to compensation" and that "[ $t$ ]hey do not include consequential or special damages." 229 The damages classification matters to buyers because consequential economic losses are clearly subject to the "notice" or "foreseeability" requirement of Hadley v. Baxendale, ${ }^{230}$ which limits liability for consequential damages to those losses that should have been contemplated by the contracting parties-or, as expressed in the Code, as losses of which the parties had a "reason to know." ${ }^{231}$ General and incidental damages are not expressly subject to such a requirement.

As to both buyers and sellers, Article 2 sets forth numerous measurement methods for general damages, the choice of which typically turns on whether the aggrieved party retains the goods. Under section $2-708$, if the

228 U.C.C. $\$ 1-305$ (a) (2009). Section 1-305(a) states in full:

The remedies provided by [the Uniform Commercial Code] must be liberally administered to the end that the aggrieved party may be put in as good a position as if the other party had fully performed but neither consequential or special damages nor penal damages may be had except as provided in [the Uniform Commercial Code] or by other rule of law.

Id. (alteration in original).

229 Id. \$ 1-305(a) cmt. 1. Section 2-715 only addresses the buyer's right to incidental and consequential damages. Such a recovery by sellers may be possible, however, if the "lost profit" language of section 2-708(2) is liberally applied. Another possible method of accomplishing the same result is for the seller to argue that the loss falls under the heading of incidental damages. Incidental damages are recoverable under section 2-710.

230 (1854) 156 Eng. Rep. 145 (Ex.).

231 See U.C.C. $\$ 2-715(2)$ (a) (2009) (stating that consequential damages include "any loss resulting from general or particular requirements and needs of which the seller at the time of contracting had reason to know" (emphasis added)); cf. Baxendale, (1854) 156 Eng. Rep. at 151. 
seller retains the goods following the buyer's repudiation or wrongful rejection, general damages will be the difference between the market price at the time and place for tender and the unpaid contract price. ${ }^{232}$ A somewhat similar market price/contract price rule for buyers appears in section $2-713 .{ }^{233}$ When the buyer has accepted the goods, the recovery rule for general damages is "loss resulting in the ordinary course of events from the seller's breach as determined in any manner which is reasonable." 234 For breach of warranty claims, however, under section 2-714 the buyer's damages are based on a "value" differential "at the time and place of acceptance," except when "special circumstances show proximate damages of a different amount." ${ }^{235}$

Despite the seeming clarity of the Code on the contours of these provisions, they leave a host of major issues unresolved. For example, the proper measure of damages for breach of the warranty of title is unclear. ${ }^{236}$ Does this situation constitute a "special circumstance" invoking the exception in section 2-714(2)? If not, the aggrieved buyer recovers only the purchase price (i.e., the difference between the value the goods would have had at the time of delivery-presumably the contract price - and their actual value to the buyer - presumably zero value if the buyer has lost possession). Complications arise if the buyer used the goods for a period of time prior to her loss of possession or if the goods have appreciated in value. Following the basic rule of section 2-714(2), the buyer in each of these situations would either be overcompensated (i.e., she would not have to pay for the value of her use) or undercompensated (i.e., she would not be compensated for the increased value of the goods). ${ }^{237}$

While it is tempting to think that making the rules even more specific would reduce the confusion and stem the tide of case law that continues to flow from the Code's remedial provisions, this approach ${ }^{238}$ would fail to get

232 See U.C.C. $\$ 2-708(1)$ (2009). The lost-profits formula from section 2-708(2) will sometimes give the seller an "out" from the market/contract rule. If the seller proceeds to resell the goods following the buyer's breach, the measure would be the difference between the resale price and the contract price under section 2-706. This assumes that the seller has complied with the mandates of that section.

233 If the aggrieved buyer makes a substitute purchase (i.e., "covers"), then compliance with section 2-712 entitles it to recover the difference between the cover price and contract price.

234 U.C.C. $\$ 2-714(1)(2009)$.

235 Id. $\$ 2-714(2)$.

236 Other examples might include the question of when market price is measured after repudiation by the seller and the difficulties that surround lost volume seller status under section 2-708(2).

237 At least one court has relied on the special circumstances language of 2-714(2) to conclude that damages should be based on the value of the goods at the time the buyer loses possession. See Itoh $\mathrm{v}$. Kimi Sales, Ltd., 345 N.Y.S.2d 416, 420 (1973).

238 See, e.g., John A. Sebert, Jr., Remedies Under Article Two of the Uniform Commercial Code: An Agenda for Review, 130 U. PA. L. REV. 360 (1981). Sebert begins his analysis with the conclusion that "[t]he portion of article 2 that seems to evidence the most pervasive problems is part 7 , which deals with remedies for breach." Id. at 363 . This is so, according to Sebert, "because the Code's remedy provisions are not sufficiently specific to provide the necessary guidance to courts and litigants." $I d$. 
at the heart of the matter: assuring full compensation for the aggrieved party. Empirical evidence suggests that courts and litigants now frequently disagree on the basic issue of which Code section governs and that outcomes sometimes have less to do with compensation than with perceptions about the intent of Llewellyn and the other drafters of the Code. ${ }^{239}$ There is little reason to think that adding to the internal complexity of the Code will ease the preoccupation of litigants and courts with issues of applicability and scope. Indeed, it seems far likelier that-to the extent that rules multiply and unanticipated situations continue to arise-disputes over which rule applies and how it applies in a given context will escalate.

In fact, the damages rules of Article 2 suffer from too great a degree of specificity. One solution to this problem of internal complexity may be to follow the lead of the unconscionability provisions and replace precise rules with general standards of compensation, such as the standard found in section 1-305..$^{240}$ Merely establishing a distinction between general damages and unusual damages foreseeable by the parties before entering into the contract, ${ }^{241}$ like those found in the unconscionability doctrine, would encourage courts to focus directly on the real-life facts of cases, combat the manipulation of language, and oblige judges to be truthful about the reasons for their decisions. ${ }^{242}$

A standard approach to damages creates another benefit as well-it provides the court with the informational advantage of hindsight, giving it

239 For example, consider an aggrieved seller for whom recovery under section 2-708(1) would be too generous. Should the buyer in such a case be permitted to restrict the seller's recovery to its actual lost profit under 2-708(2)? Although it is not clear that the drafters had such a situation in mind when they wrote section 2-708(2), at least one court has used the section to limit the sellers' recovery. See Nobs Chem., USA, Inc. v. Koppers Co., 616 F.2d 212, 215 (5th Cir. 1980) ("Had the transaction been completed, their 'benefit of the bargain' would not have been affected by the fall in market price, and they would not have experienced the windfall they otherwise would receive if the market price-contract price rule contained in $\S[2-708(1)]$ is followed.”). But see Trans World Metals, Inc. v. Southwire Co., 769 F.2d 902, 908 (2d Cir. 1985) ("Southwire argues that the 'lost profits' measure should also apply when the seller would be overcompensated by section $2-708(1)$. We disagree. . . [N]othing in the language or history of section $2-708(2)$ suggests that it was intended to apply to cases in which section 2-708(1) might overcompensate the seller.").

240 See supra note 228.

241 This standard of compensation might also include a statement that overcompensation is to be avoided. The problem of overcompensation is frequently the focus of discussion involving the availability of election of remedies under Article 2. Should, for example, a buyer who covers be permitted to seek market damages if that measure would yield a higher recovery? This and other overcompensation issues are explored in Ellen A. Peters, Remedies for Breach of Contracts Relating to the Sale of Goods Under the Uniform Commercial Code: A Roadmap for Article 2, 73 YALE L.J. 199, 256 (1963), and David H. Vernon, Expectation Damages for Breach of Contract: A Primer and Critique, 1976 WASH. U. L.Q. 179, 190-93.

242 See supra notes $116-49$ and accompanying text. 
the ability to decide cases with ex post data. ${ }^{243}$ The case of Allied Canners $\&$ Packers, Inc. v. Victor Packing Co. ${ }^{244}$ is instructive. In that case, a packing company ("Packer") contracted to sell raisins to an exporter ("Exporter") at a fixed price. ${ }^{245}$ Exporter had entered into two fixed-price resale contracts. ${ }^{246}$ Before delivery, the raisin crop was adversely affected by rains, thus causing an increase in market price. Packer was unable to obtain raisins from its supplier and breached its contract with Exporter. ${ }^{247}$ Exporter did not cover; however, it managed to have one of the resale contracts rescinded. ${ }^{248}$ The other resale buyer never demanded delivery or sued Exporter, nor did Exporter ever pay it any damages. ${ }^{249}$ Thus, Exporter's actual loss was only $\$ 4,400$, namely, its lost profits on the two resale contracts. ${ }^{250}$ Exporter sued Packer for approximately $\$ 150,000$, which was the market-contract price differential under UCC section 2-713. ${ }^{251}$ The court limited Exporter's recovery to its expected resale profit of $\$ 4,400 .^{252}$ In deciding this case, the court relied primarily on the policy, now expressed in UCC section 1-305, that an award of damages should compensate for no more than the aggrieved party's actual loss. ${ }^{253}$

Now consider the same case, but with changed facts: assume that Exporter had not yet entered into the resale contracts at the time of Packer's breach. On the delivery date, when the market price is above the contract price, Packer breaches. Shortly thereafter, the market price falls dramatically to below the price at which Exporter and other wholesalers can sell raisins. If Packer had not breached, Exporter would have lost money on resale. Once again, the issue would be whether post-breach circumstances should afford a ground for rejecting a specific Code-dictated measure of damages (the difference between contract price and market price) in order to award a sum that reflects the aggrieved party's actual economic loss. This Article argues that they should. The use of section 1-305 gives the courts that opportunity and, indeed, may obligate them to put the plaintiff in the position

243 See, e.g., Sinclair Refinery Co. v. Jenkins Petroleum Process Co., 289 U.S. 689, 698 (1933) (referring to post-breach events and in elegant terms observing that "[e]xperience is then available to correct uncertain prophecy. Here is a book of wisdom that courts may not neglect. We find no rule of law that sets a clasp upon its pages, and forbids us to look within."); Fishman v. Estate of Wirtz, 807 F.2d 520, 552 (7th Cir. 1986) (stating that "we know of no case that suggests that a value based on expectation of gain is more relevant and reliable than one derived from actual gain").

244209 Cal. Rptr. 60 (Ct. App. 1984).

245 Id. at 61.

246 Id.

247 Id.

248 Id. at 61-62.

249 Id. at 62

250 Allied Canners \& Packers, 209 Cal. Rptr. at 64.

251 Id. at 62.

252 Id. at 66 \& n.8.

253 Id. at 66. 
she would have attained had performance been rendered in accordance with the contract, but not in a better position. ${ }^{254}$ As illustrated by this example, a remedies regime consisting of standards can better accommodate the importance of post-breach events.

The case for a general standard of recovery becomes even stronger if the existing specific measures of damages cannot realistically be characterized as bedrock rules on which parties actually rely. Indeed, it is hard to imagine that any particular measure of damages, whatever it may be, is seriously considered by the parties or their lawyers prior to breach. In the real world, the dynamics of day-to-day business contracting suggest that busy parties may proceed with little thought to even critical terms like price and delivery date, let alone damages. ${ }^{255}$ Empirical evidence indicates that the threat of extralegal sanctions alone is sufficient to shape the expectations of parties having a history of prior dealings. ${ }^{256}$ In addition, cognitive psychologists have demonstrated that, generally speaking, people tend to underestimate the probability of bad things happening. ${ }^{257}$ Thus, they may believe that their counterparty's breach is far less likely than it actually is. Finally, it must be remembered that the damages provisions in Article 2 are default rules. Parties who really care about their remedies have the right to shape them ex ante to their particular requirements, and it is reasonable to assume that they would. ${ }^{258}$

Considering these factors, the justification for retaining specific methods of measuring damages in Article 2 is significantly weakened. Moreover, other sections of the Code provide ample instances of statutory damages provisions lacking such specific prescribed methods of calculation. Scattered throughout the Code are sections that provide for the recovery of

254 What has been said for aggrieved buyers applies with equal force to the disappointed seller. See, e.g., Nobs Chem., USA, Inc. v. Koppers Co., 616 F.2d 212, 214-16 (5th Cir. 1980) (restricting seller to its recovery of lost profits under section 2-708(2) where seller's lost profits were less than its market damages).

255 Indeed, many aspects of Article 2 are premised on the rough and tumble world of real life contracting carried out by underlings. In this respect, sections 2-204, 2-206, and 2-207 dispense with many of the formalities in contracting, make it unnecessary for a court to find the exact moment of formation, and recognize that parties may leave open one or more terms. Other sections are designed to fill these gaps. See, e.g., U.C.C. § 2-305 (2009) ("Open Price Term"); id. § 2-309(1) ("The time for shipment or delivery ... if not . . agreed upon shall be a reasonable time.").

256 See, e.g., Jason Scott Johnston, The Statute of Frauds and Business Norms: A Testable GameTheoretic Model, 144 U. PA. L. REV. 1859, 1888 (1996) ("Disputes involving repeat players should not result in reported decisions because extralegal sanctions take care of enforcement problems ....").

257 See, e.g., Melvin Aron Eisenberg, The Limits of Cognition and the Limits of Contract, 47 STAN. L. REV. 211, 216 (1995) ("[E]vidence shows that as a systematic matter, people are unrealistically optimistic."); Robert A. Hillman, The Limits of Behavioral Decision Theory in Legal Analysis: The Case of Liquidated Damages, 85 CORNELL L. REV. 717, 723 (2000) (explaining that decision makers are overconfident "based on their belief that adverse low-probability risks will not occur").

258 See U.C.C. $\S 2-718$ (2009) ("Liquidation or Limitation of Damages; Deposits"); id. § 2-719 ("Contractual Modification or Limitation of Remedy"). 
"damages" with no guidance whatsoever on how those damages must be measured. ${ }^{259}$ As a practical matter, this means that the applicable measurement method is the compensation standard of section 1-305. To proceed one step further and make the section 1-305 standard universal would be an appropriate and beneficial response to the current level of internal complexity of the Code. Moreover, even if we accept, arguendo, the proposition that the specific measures in Article 2 are helpful, one may at least ask whether it is healthy for courts to purport to be bound by them when in fact they are free under section 1-305 to disregard them entirely.

\section{B. Suggestion Two: Consolidation of Warranty and Tort Law}

In most jurisdictions, existing law provides purchasers of goods, and sometimes third parties who suffer personal injury or property loss, with two regimes under which they may seek recovery: tort law and contract law. ${ }^{260}$ Although tort law makes available actions due to negligence, the most significant tort theory open to plaintiffs in cases of this kind is strict liability. ${ }^{261}$ In contract, the competing theory of significance is breach of the

259 See, e.g., id. \$ 4-402 ("A payor bank is liable to its customer for damages caused by the wrongful dishonor of an item."); id. §5-111(b) ("If an issue wrongfully dishonors a draft or demand presented under a letter of credit or honors a draft or demand in breach of its obligation to the applicant, the applicant may recover damages resulting from the breach ...."); id. $\S 7-203$ ("A party to or purchaser for value in good faith of a document of title . . . that relies upon the description of the goods in the document may recover from the issuer damages caused by the nonreceipt or misdescription of the goods ...."); id. § 9-625(b) (" $\mathrm{A}]$ person is liable for damages in the amount of any loss caused by a failure to comply with this article.").

260 Courts seem bent on carving out a separate niche for tort and warranty based on the type of damages involved. This effort has led to the much-litigated "economic loss rule." The question of whether injury to the property itself could be recovered in tort has yielded inconsistent answers. The poles are represented by the majority-or California-position (i.e., where a defective product causes only monetary damages, warranty liability preempts the field), see, e.g., Seely v. White Motor Co., 403 P.2d 145, 150-51 (Cal. 1965), and the minority-or New Jersey-position (i.e., allowing tort recovery for injury to the product itself whether or not the defect created an unreasonable risk of harm), see, e.g., Santor v. A \& M Karagheusian, Inc., 207 A.2d 305, 308-10 (N.J. 1965). In between these two poles are intermediate positions, seeking to differentiate between, for example, "the disappointed users . . . and the endangered ones," see, e.g., Russell v. Ford Motor Co., 575 P.2d 1383, 1387 (Or. 1978), or between "the nature of the defect, the type of risk, and the manner in which the injury arose," see, e.g., Pa. Glass Sand Corp. v. Caterpillar Tractor Co., 652 F.2d 1 165, 1173, 1175 (3d Cir. 1981) (holding that the situation in question resulted in physical injury and not merely economic loss allowing the buyer to seek recovery under tort law).

261 A cause of action for negligence generally requires plaintiffs to establish that the manufacturer or seller has failed to use reasonable care to eliminate foreseeable dangers that create an unreasonable risk of harm to the person or property of another. See RESTATEMENT (SECOND) OF TORTS $\S 395$ (1965). In the case of manufacturing defects and defendants that are not manufacturers, this may be impossible to do. Whereas negligence focuses on the actions of the defendant, a strict liability claim focuses on the product. Thus, it is not surprising that plaintiffs exhibit a preference for the latter theory. Justice Tray- 
implied warranty of merchantability. ${ }^{262}$ With two avenues available to plaintiffs, a bifurcated system of products liability law has emerged, adding confusion to the legal landscape. ${ }^{263}$ Perhaps the most well-known and glaring example of the results of such confusion is the New York Court of Appeals opinion in Denny v. Ford Motor Co. ${ }^{264}$

In that case, Mrs. Denny was injured when her Ford Bronco II ("Bronco") overturned as she attempted to avoid a deer in the road. ${ }^{265}$ She and her husband sued Ford Motor Co. ("Ford") in federal court, pleading claims

nor's opinion for a unanimous court in Greenman v. Yuba Power Products, Inc., 377 P.2d 897, 898 (Cal. 1963), was the first judicial recognition of the new common law tort of strict liability. It was soon, thereafter, enshrined in the Restatement (Second) of Torts as section 402A. RESTATEMENT (SECOND) OF TORTS $\S 402 A$ (1965). Under this section, the seller is liable for physical injury to the person or property of the ultimate user or consumer caused by a product that is defective and unreasonably dangerous. Only a few states have rejected the tort. See, e.g., Cline v. Prowler Indus. of Md., Inc., 418 A.2d 968, 974 (Del. 1980) (holding that the Code had preempted the sales field and, therefore, it alone provided the sole recourse for recovery). In 1988, the ALI promulgated the Restatement (Third) of Torts: Products Liability. Section 1 provides that "[o]ne engaged in the business of selling or otherwise distributing products who sells or distributes a defective product is subject to liability for harm to persons or property caused by the defect." RESTATEMENT (THIRD) OF TORTS: Products LIABILITY $§ 1$ (1998). Section 2 then proceeds to set forth three separate standards for determining whether a product is defective, depending on whether the claimed defect is (1) a manufacturing defect, (2) a design defect, or (3) a failure to warn or give adequate instructions. For further discussion of the concept of defect, see infra notes 265-79 and accompanying text.

262 UCC Article 2 recognizes several "gap-filling" warranties that are part of the contract of the parties unless they are excluded or modified by agreement. Section 2-314 provides that if the seller is "a merchant with respect to goods of that kind," then "a warranty that the goods shall be merchantable is implied in a contract for their sale." U.C.C. $\$ 2-314(1)$ (2009). Determining the level of section 2-314 quality that is required by the term "merchantable" obviously calls for a fact-intensive inquiry guided by the criteria of section 2-314(2)(a)-(f). See id. $\$ 2-314(2)(a)-(\mathrm{f})$. The usual focus in a products liability case is whether the goods were "fit for the ordinary purposes for which such goods are used." Id. $\$ 2-314(2)(\mathrm{c})$. Because the warranty of merchantability is imposed on parties by law based on public policy, it looks strikingly similar to the tort doctrine of strict liability-hence, Prosser's colorful observation that implied warranty is "a freak hybrid born of the illicit intercourse of tort and contract." William L. Prosser, The Assault upon the Citadel (Strict Liability to the Consumer), 69 Y ALE L.J. 1099, 1126 (1960). In addition to the implied warranty of merchantability, a plaintiff may sometimes be able to claim a breach of an express warranty under section 2-313 or the warranty of fitness for a particular purpose under section 2-315. Since these two warranties are not designed to address the basic safety of goods, they will be largely ignored in the discussion that follows.

263 This is not an original observation. See, e.g., Sundberg v. Keller Ladder, 189 F. Supp. 2d 671, 676 (E.D. Mich. 2002) ("Although the separate action of 'implied warranty' had long co-existed with more formal product liability tort actions, it became duplicative and confusing."); RESTATEMENT (THIRD) OF TORTS: PRODUCTS LIABILITY $\$ 2 \mathrm{cmt}$. n (1998) ("To allow two or more factually identical risk-utility claims to go to a jury under different labels, whether 'strict liability,' 'negligence,' or 'implied warranty of merchantability,' would generate confusion and may well result in inconsistent verdicts."); James J. White, Evaluating Article 2 of the Uniform Commercial Code: A Preliminary Empirical Expedition, 75 MICH. L. REV. 1262, 1270 (1977) ("[D]rafters . . did not foresee the considerable potential for confusion between the Code provisions and such strict tort doctrines.").

264662 N.E.2d 730 (N.Y. 1995).

265 Id. at 731 . 
under three alternate causes of action: negligence, strict liability, and breach of warranty. ${ }^{266}$ The gist of the Dennys' position was that "four-wheel-drive utility vehicle[s]," such as the Bronco, are less stable and present a higher risk of rollover than standard automobiles when used for on-road travel ${ }^{267}$ and that Ford's marketing of the vehicle led them to believe that it was safe and perfectly suitable for suburban and city driving. ${ }^{268}$ On these facts, the jury returned a verdict in favor of Ford on the strict liability claim (i.e., "the Bronco [] was not defective") ${ }^{269}$ and against Ford on the warranty claim (i.e., the Bronco was unmerchantable). ${ }^{270}$ Ford argued that because these two conclusions presented an irreconcilable conflict, it was entitled to a new trial. The trial court disagreed, and Ford appealed.

As the issues involving the proper relationship between strict liability and breach of warranty causes of action were matters of New York law, the Second Circuit certified three questions to the New York Court of Appeals. ${ }^{271}$ In its answer, the New York court responded that: (1) the strict liability claim and the breach of warranty claim were not identical; (2) the strict liability claim was not broader than or encompassing of the warranty claim; and (3) the jury's conclusion that the Bronco was not defective was reconcilable with its conclusion that the Bronco was unmerchantable. ${ }^{272}$ The majority pointed out that although tort theories of products liability and the implied warranty of merchantability coexist and are frequently used in tandem, each cause of action requires a subtly different approach to the question of design defect. ${ }^{273}$ Liability under the former is to be determined by application of a risk-utility balancing test that requires evaluation of a number of "policy-driven factors." 274 In this respect, there is little difference between an action in strict liability and an action in negligence because both theories originate in tort law and are driven by considerations of social poli-

266 Id.

267 Id. at 732. The design characteristics that made the Bronco less stable than ordinary vehicles when driven on-road-high center of gravity, short wheel base, and specially tailored suspension system-are what gave it its off-road capabilities. $I d$.

268 Id.

269 Id. at 733 (internal quotation marks omitted).

270 Denny, 662 N.E.2d at 733 . The negligence claim was rejected on proximate cause grounds. Id. at 733 n.1.

271 Denny v. Ford Motor Co., 42 F.3d 106, $111-13$ (2d Cir. 1994).

272 Denny, 662 N.E. 2 d at 739.

273 Id. at $734-35$.

274 Id. at 735 . Some of these factors are:

(1) the product's utility to the public as a whole, (2) its utility to the individual user, (3) the likelihood that the product will cause injury, (4) the availability of a safer design, (5) the possibility of designing and manufacturing the product so that it is safer but remains functional and reasonably priced, (6) the degree of awareness of the product's potential danger that can reasonably be attributed to the injured user, and (7) the manufacturer's ability to spread the cost of any safety-related design changes. 
cy and risk allocation. ${ }^{275}$ The court, therefore, concluded that the jury might have reasonably believed that the Bronco's utility as an off-road vehicle outweighed the risk of rollover accidents when it was used for on-road driving.

The similarity does not hold true, however, with respect to product merchantability principles. Because implied warranty theory is grounded in contract, if a plaintiff proves that a product has failed to satisfy ordinary consumer expectations, then the product is defective and the defendant will be held strictly liable for resulting injuries. ${ }^{276}$ Because the Bronco had been marketed as a vehicle that was appropriate for everyday highway and street driving, the court found it plausible that Ford had created the expectation that routine driving was the "ordinary purpose" for which the Bronco was sold and then found that the Bronco was not "fit" for that purpose. ${ }^{277} \mathrm{By}$ identifying different tests- "consumer expectations" for warranty liability and "risk-utility" for strict liability-the court was able to conclude that the two portions of the jury's verdict were reconcilable. ${ }^{278}$

In addition to competing notions of the meaning of "defective," there are many other rule differences between the contract and tort legal regimes and their respective approaches to product liability, each of which produces or contributes to uncertainty and unpredictability when the two regimes compete. For example, the measurement of damages may be different, with only tort law permitting recovery of damages for pain and suffering and, in appropriate cases, punitive damages. In addition, under the contract regime only, the implied warranty of merchantability can be freely disclaimed ${ }^{279}$ and remedies limited by including appropriate terms in the agreement between the parties. ${ }^{280}$ Another difference exists in the applicability of statutes of limitation: the warranty statute in contract begins to run at the time the goods are tendered, while in tort the statute typically begins to run at the time of the injury. Yet another difference is that, unlike breach of warranty

275 Id

276 Id. at 736 .

277 Id. at 738 (internal quotation marks omitted).

278 Denny, 622 N.E.2d at 738 . The Court observed that the case was unusual in that "the "ordinary purpose' for which the product was marketed and sold to the plaintiff was not the same as the utility against which the risk was to be weighed." Id. at 739.

279 See U.C.C. $\$ 2-316(2009)$.

280 It is not unusual for the contract to contain a clause that excludes recovery for consequential damages. See id. $\S 2-719(3)$. Moreover, the buyer may agree to an exclusive remedy such as "repair and replacement of non-conforming goods or parts," which would effectively preclude the recovery of damages. Id. $\S 2-719(1)$ (a). The approach of the Restatement (Third) of Torts: Products Liability is quite different:

Disclaimers and limitations of remedies by product sellers or other distributors, waivers by product purchasers, and other similar contractual exculpations, oral or written, do not bar or reduce otherwise valid products liability claims against sellers or other distributors of new products for harm to persons.

RESTATEMENT (THIRD) OF TORTS: PRODUCTS LIABILITY $§ 18$ (1998). 
actions in contract, tort actions require no privity of contract. ${ }^{281}$ Finally, notice of breach is a prerequisite to recovery in an action for breach of warranty, while no such notice is required to recover in tort. ${ }^{282}$

The real policy question is whether it is socially more efficient to have one products liability regime that serves the instrumentalist goal of encouraging sellers to respond with safer and better products. This Article argues that it is, and that it is fundamentally unreasonable and inconsistent for different rules to apply to the same injury based merely on the form of the pleading. ${ }^{283}$ Several consolidation alternatives (varying in magnitude) are possible, and entirely aside from any normative considerations as to the substance of specific rules, this Article submits that consolidation of the various doctrinal categories of liability in and of itself would improve the current system.

The most far-reaching approach to consolidation would be to have one source of law govern all cases in which a product malfunctions and harm is caused to person, property, or purse. Using this approach, legal distinctions based on the type of loss (e.g., economic or personal injury) and type of transaction (e.g., sale or lease) would vanish. It is unrealistic, however, to expect such radical change to emanate from courts bound by precedent reflecting widely disparate approaches. Thus, reform of this nature and magnitude would require legislative intervention. At least one commentator has made a valiant attempt at such legislative synthesis. ${ }^{24}$ Professor Linda Rusch's proposed statute improves upon both existing state products liability statutes ${ }^{285}$ and the federally created Model Uniform Products Liability Act, ${ }^{286}$ each of which melds the various theories of recovery (i.e., negligence, strict liability, and warranty) into a single claim. Although these

281 See RESTATEMENT (THIRD) OF TORTS: PRODUCTS LIABILITY $\$ 1 \mathrm{cmt}$. a (1998) ("Strict liability in tort for defectively manufactured products merges the concept of implied warranty, in which negligence is not required, with the tort concept of negligence, in which contractual privity is not required."). UCC Article 2 does contain a provision that extends a warranty made directly to a buyer to a class of third parties not in privity with the warrantor. See U.C.C. $\S 2-318$ (2009).

282 See U.C.C. § 2-607(3)(a) (2009).

283 Accordingly, at least some courts have ignored the characterization of a plaintiff's claim when deciding the applicable statute of limitations. See, e.g., Hambleton v. R.G. Barry Corp., 465 N.E.2d 1298, 1302 (Ohio 1984) ("[I]n determining which limitation period will apply, courts must look to the actual nature or subject matter of the case, rather than to the form in which the action is pleaded.").

284 See generally Linda J. Rusch, Products Liability Trapped by History: Our Choice of Rules Rules Our Choices, 76 TEMP. L. REv. 739 (2003). Professor Rusch explains as follows:

Doctrines that attempt to define the boundary between tort and contract concerns in determining the obligation of a product seller for product malfunction result in a wasteful litigation scheme, work to the disadvantage of businesses that suffer harm due to product malfunction, and obscure the incentive for a product seller to produce products with the appropriate degree of risk.

Id. at 758 .

285 See, e.g., KAN. STAT. ANN. $\S \S 60-3301$ to -3307 (2005); N.J. STAT. ANN. $\S \S 2 A: 58 \mathrm{C}-1$ to -11

(West 2010).

286 See Model Uniform Product Liability Act, 44 Fed. Reg. 62,714 (Oct. 31, 1979). 
statutory measures are a significant step in the right direction, they do not deal with economic harm (i.e., harm other than harm to persons or property). Thus, unlike Rusch's proposed statute, the economic loss rule would continue to control the source of law issue.

A less radical approach to reducing complexity is available via a strategy that does not unify traditional causes of action, but does address the Denny problem. Recall that the Court in that case determined that the standard in tort for an unreasonably dangerous product was not the same as that in warranty for an unmerchantable product. ${ }^{287}$ Yet, in a personal injury or property damage case, whether the claim is based on negligence, breach of implied warranty, or strict liability, the product must be found to be unsafe (i.e., dangerous by some measure) in order to be actionable. There is simply no good reason why the applicable measure for determining whether a product is unsafe should not be the same for all three theories. Not surprisingly, the Restatement (Third) of Torts espouses this position, ${ }^{288}$ and the drafting committee charged with amending UCC Article 2 agreed. ${ }^{289}$ In other words, the official position of both the ALI and ULC is that the New York Court of Appeals got it wrong.

Clearly, burdening a product liability case with the conceptual baggage of discrete liability regimes when the claim rests on the same factual predicate adds nothing but confusion. How can jurors make an informed determination about whether to impose liability? Perhaps the honest answer is that they must guess. A candid acknowledgment of the lack of clarity that currently clouds the products liability system suggests that the time has come to abolish any distinctions between contact and tort inherited from the formulary writ system.

\section{CONCLUSION}

Driven by social and technological change, commercial law is growing at a rapid rate. This has led to a corresponding growth in the law's complexity. This complexity can be viewed for purposes of analysis as falling into two categories, that which is internal to a legal regime (i.e., internal complexity) and that which results from competing regimes (i.e., external complexity). Evaluating the real costs associated with complexity can be a

\footnotetext{
287 See Denny v. Ford Motor Co., 662 N.E.2d 730, 739 (N.Y. 1995).

288 A comment to the Restatement section 2 states:

Warranty. Liability for harm caused by product defects imposed by the rules stated in this chapter is tort liability, not liability for breach of warranty under the Uniform Commercial Code (U.C.C.). Courts may characterize claims under this Chapter as claims for breaches of the implied warranty of merchantability. But in cases involving defect-caused harm to persons or property, a well-coordinated body of law dealing with liability for such harm arising out of the sale of defective products would adopt the tort definition of product defect.

RESTATEMENT (THIRD) OF TORTS: PRODUCTS LIABILITY $§ 2 \mathrm{cmt} . \mathrm{r}$ (1998).

289 See U.C.C. § $2-314 \mathrm{cmt} .7$ (2009).
} 
difficult and frustrating task, and the effects of complexity remain unquantified despite general acknowledgement that the costs exist and are substantial. While their full extent may be unknown, these costs are many and varied, ranging from a regrettable impairment of judicial candor ${ }^{200}$ to a significant increase in the cost of legal services. ${ }^{291}$

Professor Grant Gilmore once observed that "[i]n the growth of the law there are periods of relative stability and periods of rapid change. The introduction of some radically new element into a stable situation leads to a pendulum-like swing from simplicity to complexity and then, as the new element becomes assimilated, back towards simplicity." ${ }^{292}$ While Gilmore's pendulum swing does occur, it is unrealistic to think that it would necessarily do so of its own accord and in the absence of a conscious judicial or legislative push. Indeed, Gilmore and the other UCC drafters acknowledged this need in codifying the doctrine of unconscionability and in consolidating the law of secured transactions into a single statute. The respective minimalist strategies at play in these improvements-shifting from a rule to a standard in the former case and the establishment of a unitary source of law in the latter-have proven to be particularly useful strategies in reducing the complexity of pre-Code law and ones that should serve as models for continued improvements.

Simplification strategies such as those described in this Article are amenable to applications throughout commercial law. Thus, the law of damages under the Code could be improved by substituting a statutory standard of compensation for the current four-tier damages classification system. ${ }^{293}$ Similarly, the law of products liability would benefit from merging the multiple traditional causes of action into a single theory of product defect. ${ }^{294}$ No doubt, identifying subject areas in which these strategies might be usefully employed and then prodding courts and legislatures into meaningful action will be daunting undertakings. Yet the gains to be realized by efforts to overcome the internal and external complexity of commercial law provide powerful incentives to invest in this difficult work. The time has come to take seriously both commercial law complexity and its very real costs.

290 See supra notes $32-52$ and accompanying text.
291 See supra notes 53-84 and accompanying text.
292 GILMORE, supra note $151, \S 9.1$, at 288 .
293 See supra notes $228-59$ and accompanying text.
294 See supra notes $260-88$ and accompanying text. 